\title{
New national and regional bryophyte records, 49
}

\author{
Ellis, L. T.
}

2016-09

Ellis , L T , Agcagil , E , Kirmaci , M , Aleffi , M , Bakalin , V A, Bednarek-Ochyra , H , Cykowska-Marzencka , B , Stryjak-Bogacka, M , Bojaca, G F P , Fantacelle , L B , Araujo , C A T, Maciel-Silva , A S , Bruno Silva , J , Calleja , J A , Cano , M J , Castillo Diaz , J , Gabriel , R, Dias dos Santos , N, Enroth , J , Erzberger , P, Garilleti , R, Hajek , M , Hedenäs , L , Heras , P , Infante , M , Kiebacher , T , Koczur , A , Krawczyk , R , Kucera , J , Lebouvier, M , Lüth , M , Mazimpaka, V , Vigalondo , B , Lara , F , Nagy , J , Nemeth , C , pÿKovács , A, Nobis, M , We(grzyn, M , Wietrzyk, P, Norhazrina, N , Vanderpoorten , A, Nowak, A, Poponessi , S, Gigante, D, Venanzoni , R, Plasek, V , Rangel Germano , S , Schäfer-Verwimp , A, Sergio , C , Claro , D , Garcia , C A, Shirzadian , S , Akhoondi pÿDarzikolaei , S , Stebel , A, Suleiman, M , Yong , K -T , Virchenko , V M , Voncina, G , Yoon , Y -J , Choi , H -G \& Kim , J H 2016 , ' New national and regional bryophyte records, 49 ' , Journal of Bryology, vol. 38 , no. 4 , pp. 327-347 . https://doi.org/10.1080/03736687.2016.1225777

http://hdl.handle.net/10138/175823

https://doi.org/10.1080/03736687.2016.1225777

publishedVersion

Downloaded from Helda, University of Helsinki institutional repository.

This is an electronic reprint of the original article.

This reprint may differ from the original in pagination and typographic detail.

Please cite the original version. 


\section{New National and Regional Bryophyte Records, 49}

L. T. Ellis, E. Agcagil, M. Kırmacı, M. Aleffi, V. A. Bakalin, H. Bednarek-Ochyra,

B. Cykowska-Marzencka, M. Stryjak-Bogacka, G. F. P. Bojaca, L. B. Fantacelle, C. A. T. Araújo, A. S. Maciel-Silva, J. Bruno Silva, J. A. Calleja, M. J. Cano, J. Castillo Diaz, R. Gabriel, N. Dias dos Santos, J. Enroth, P. Erzberger, R. Garilleti, M. Hájek, L. Hedenäs, P. Heras, M. Infante, T. Kiebacher, A. Koczur, R. Krawczyk, J. Kučera, M. Lebouvier, M. Lüth, V. Mazimpaka, B. Vigalondo, F. Lara, J. Nagy, Cs. Németh, A. Kovács, M. Nobis, M. Węgrzyn, P. Wietrzyk, N. Norhazrina, A. Vanderpoorten, A. Nowak, S. Poponessi, D. Gigante, R. Venanzoni, V. Plášek, S. Rangel Germano, A. Schäfer-Verwimp, C. Sérgio, D. Claro, C. A. Garcia, S. Shirzadian, S. Akhoondi Darzikolaei, A. Stebel, M. Suleiman, K.-T. Yong, V. M. Virchenko, G. Vončina, Y.-J. Yoon, H.-G. Choi \& J. H. Kim

To cite this article: L. T. Ellis, E. Agcagil, M. Kırmacı, M. Aleffi, V. A. Bakalin, H. Bednarek-Ochyra, B. Cykowska-Marzencka, M. Stryjak-Bogacka, G. F. P. Bojaca, L. B. Fantacelle, C. A. T. Araújo, A. S. Maciel-Silva, J. Bruno Silva, J. A. Calleja, M. J. Cano, J. Castillo Diaz, R. Gabriel, N. Dias dos Santos, J. Enroth, P. Erzberger, R. Garilleti, M. Hájek, L. Hedenäs, P. Heras, M. Infante, T. Kiebacher, A. Koczur, R. Krawczyk, J. Kučera, M. Lebouvier, M. Lüth, V. Mazimpaka, B. Vigalondo, F. Lara, J. Nagy, Cs. Németh, A. Kovács, M. Nobis, M. Węgrzyn, P. Wietrzyk, N. Norhazrina, A. Vanderpoorten, A. Nowak, S. Poponessi, D. Gigante, R. Venanzoni, V. Plášek, S. Rangel Germano, A. Schäfer-Verwimp, C. Sérgio, D. Claro, C. A. Garcia, S. Shirzadian, S. Akhoondi Darzikolaei, A. Stebel, M. Suleiman, K.-T. Yong, V. M. Virchenko, G. Vončina, Y.-J. Yoon, H.-G. Choi \& J. H. Kim (2016): New National and Regional Bryophyte Records, 49, Journal of Bryology, DOI: 10.1080/03736687.2016.1225777

To link to this article: http://dx.doi.org/10.1080/03736687.2016.1225777

Published online: 28 Sep 2016.

Submit your article to this journal

Article views: 11 
Full Terms \& Conditions of access and use can be found at

http://www.tandfonline.com/action/journallnformation?journalCode=yjbr20 


\title{
New National and Regional Bryophyte Records, 49
}

\author{
L. T. Ellis ${ }^{1}$, E. Agcagil'2, M. Kırmaci ${ }^{2}$, M. Aleffi ${ }^{3}$, V. A. Bakalin4,5, H. Bednarek-
} Ochyra $^{6}$, B. Cykowska-Marzencka 6 , M. Stryjak-Bogacka ${ }^{6}$, G. F. P. Bojaca7, L. B. Fantacelle7, C. A. T. Araújo7, A. S. Maciel-Silva7, J. Bruno Silva8, J. A. Calleja 9,10, M. J. Cano ${ }^{11}$, J. Castillo Diaz ${ }^{12}$, R. Gabriel ${ }^{12}$, N. Dias dos Santos ${ }^{13}$, J. Enroth ${ }^{14}$, P. Erzberger ${ }^{15}$, R. Garilleti ${ }^{16} \odot$, M. Hájek ${ }^{17}$, L. Hedenäs ${ }^{18} \odot$, P. Heras ${ }^{19}$, M. Infante ${ }^{20}$, T. Kiebacher ${ }^{21}$, A. Koczur ${ }^{22}$, R. Krawczyk ${ }^{23}$, J. Kučera ${ }^{24} \odot$, M. Lebouvier ${ }^{25}$, M. Lüth ${ }^{26}$, V. Mazimpaka ${ }^{27}$, B. Vigalondo ${ }^{27}$, F. Lara ${ }^{27}$, J. Nagy ${ }^{28}$, Cs. Németh ${ }^{28}$, A. Kovács ${ }^{28}$, M. Nobis ${ }^{29}$, M. Wegrzyn ${ }^{29}$, P. Wietrzyk ${ }^{29}$, N. Norhazrina ${ }^{30}$, A. Vanderpoorten ${ }^{30}$, A. Nowak ${ }^{31}$, S. Poponessi32, D. Gigante ${ }^{32}$, R. Venanzoni32, V. Plášek 33, S. Rangel Germano34, A. Schäfer-Verwimp ${ }^{35}$, C. Sérgio36, D. Claro ${ }^{36}$, C. A. Garcia ${ }^{36}$, S. Shirzadian 37, S. Akhoondi Darzikolaei37, A. Stebel ${ }^{38}$, M. Suleiman ${ }^{39}$, K.-T. Yong ${ }^{40}$, V. M. Virchenko41, G. Vončina ${ }^{42}$, Y.-J. Yoon ${ }^{43}$, H.-G. Choi 43 and J. H. Kim 43

\footnotetext{
${ }^{1}$ The Natural History Museum, London, UK, ${ }^{2}$ Adnan Menderes Üniversitesi, Kepez-Aydın, Turkey, ${ }^{3}$ University of Camerino, Camerino (MC), Italy, ${ }^{4}$ Botanical Garden-Institute, Vladivostok, Russia, ${ }^{5}$ Institute of Biology and Soil Science, Vladivostok, Russia, ${ }^{6} \mathrm{~W}$. Szafer Institute of Botany, Polish Academy of Sciences, Kraków, Poland, ${ }^{7}$ Departamento de Botânica-Instituto de Ciências Biológicas, Universidade Federal de Minas Gerais (UFMG), Belo Horizonte, Minas Gerais, Brazil, ${ }^{8}$ Departament of Botany, Federal University of Pernambuco, Recife, PE, Brazil, ${ }^{9}$ Departamento de Biología Animal, Biología Vegetal y Ecología (Botánica), Universidad Autónoma de Barcelona, Barcelona, Spain, ${ }^{10} \mathrm{CREAF}$, Universidad Autónoma de Barcelona, Barcelona, Spain,

${ }^{11}$ Departamento de Biología Vegetal (Botánica), Universidad de Murcia, Murcia, Spain, ${ }^{12}$ Departamento de Ciências Agrárias, CE3c, Centre for Ecology, Evolution and Environmental Changes/Azorean Biodiversity Group \& University of Azores, Azores, Portugal, ${ }^{13}$ Departament of Botany, Federal Rural University of Rio de Janeiro, Seropédica, RJ, Brazil, ${ }^{14}$ Department of Biosciences and Botanical Museum, University of Helsinki, Helsinki, Finland, ${ }^{15}$ Berlin, Germany, ${ }^{16}$ Departamento de Botánica y Geología, Universidad de Valencia, Valencia, Spain, ${ }^{17}$ Masaryk University, Brno, Czech Republic, ${ }^{18}$ Department of Botany, Swedish Museum of Natural History, Stockholm, Sweden, ${ }^{19}$ Museo de Ciencias Naturales de Álava, Vitoria-Gasteiz, Spain, ${ }^{20}$ Conservatoire Botanique National des Pyrénées et Midi-Pyrénées, Bagnères-de-Bigorre, France, ${ }^{21}$ Swiss Federal Research Institute WSL, Birmensdorf, Switzerland, ${ }^{22}$ Polish Academy of Sciences, Kraków, Poland, ${ }^{23}$ Department of Nature Conservation, Maria Curie-Skłodowska University, Lublin, Poland, ${ }^{24}$ University of South Bohemia, České Budějovice, Czech Republic, ${ }^{25}$ CNRS UMR 6553, Université de Rennes 1, Rennes, France, ${ }^{26}$ Freiburg im Breisgau, Germany, ${ }^{27}$ Departamento de Biología (Botánica), Universidad Autónoma de Madrid, Spain, ${ }^{28}$ Department of Botany, Faculty of Horticultural Sciences, Szent István University, Budapest, Hungary, ${ }^{29}$ Jagiellonian University, Kraków, Poland, ${ }^{30}$ University of Liege, Institute of Botany, Liege, Belgium, ${ }^{31}$ University of Opole, Opole, Poland, ${ }^{32}$ University of Perugia, Perugia, Italy, ${ }^{33}$ University of Ostrava, Ostrava, Czech Republic, ${ }^{34}$ Departament of Botany, Estadual University of Paraíba, Campina Grande, PB, Brazil, ${ }^{35}$ Herdwangen-Schönach, Germany, ${ }^{36}$ Museu Nacional de História Natural e da Ciência, Universidade de Lisboa, Lisbon, Portugal, ${ }^{37}$ Iranian Research Institute of Plant Protection, Agricultural Research Education and Extension Organization (AREEO), Tehran, Iran, ${ }^{38}$ Department of Pharmaceutical Botany, Medical University of Silesia in Katowice, Sosnowiec, Poland, ${ }^{39}$ Institute for Tropical Biology and Conservation, Universiti Malaysia Sabah, Kota Kinabalu, Sabah, Malaysia, ${ }^{40}$ Faculty of Science, Institute of Biological Sciences, University of Malaya, Kuala Lumpur, Malaysia, ${ }^{41}$ Department of Lichenology and Bryology, Institute of Botany, National Academy of Sciences of Ukraine, Kiev, Ukraine, ${ }^{42}$ Pieniny National Park, Krościenko nad Dunajcem, Poland, ${ }^{43}$ Korea Polar Research Institute, KIOST, Incheon, Korea
} 
1. Alleniella complanata (Hedw.) S.Olsson, Enroth \& D.Quandt

Contributor: J. Enroth

Uganda: 'Mont Elgon, rochers', 23 February 1974, leg. S. Lisowski 6577 (H, KRAM), and $4100 \mathrm{~m}$, leg. S. Lisowski 3433 (KRAM).

This is a temperate-boreal northern hemisphere species, in tropical regions known only from the East African mountains, and extending down to South Africa (Blockeel et al., 2006c). In East Africa it was first reported [as Neckera complanata (Hedw.) Huebener var. maxima Dixon] from Kenya (Mt Kenya, at $3000 \mathrm{~m}$ ) by Dixon (1918), and it also occurs in the Taita Hills (Mbololo, at $1650 \mathrm{~m}$ ) in the SE part of the country (Bytebier \& Chuah-Petiot, 2002). It was reported from Tanzania (Mt Meru, at $2375 \mathrm{~m}$ ) by Blockeel et al. (2003). The South African collections came from much lower altitudes (400 and $450 \mathrm{~m})$.

The African specimens reported by Bytebier \& Chuah-Petiot (2002), Blockeel et al. (2003, 2006c) were all epiphytic. The present Ugandan specimens were collected on rocks. Altitude $(4100 \mathrm{~m})$ is given on only one of the two specimens, but as both were collected the same day, the other one probably comes from an approximately similar altitude. They do not represent Dixon's (1918) var. maxima, as the shoots are less than $5 \mathrm{~cm}$ long; in var. maxima they were up to $15 \mathrm{~cm}$ long. The leaves in the Ugandan specimens are slightly narrower than is typical for the species, but otherwise the specimens agree well with the rather variable $A$. complanata.

\section{Andreaea flexuosa $\mathrm{R}$.Br.bis}

\section{Contributor: H. Bednarek-Ochyra}

Falkland Islands: East Falkland, Stanley Harbour, $51^{\circ} 41^{\prime} \mathrm{S}, 57^{\circ} 52^{\prime} \mathrm{W}$, on block of sandstone [Pí lös sandsten], 14 December 1907, leg. C. Skottsberg 119 [Expeditio suecica 1907-1909] (LD, PC, S).

Although Andreaea flexuosa was described from New Zealand relatively early (Brown, 1893), it remained a neglected and poorly known species for over a century, until Murray (2006) recorded it from many sites in SE Australia and Tasmania. The species is distinct and readily known by a set of gametophyte characters, including narrow, scarcely vaginant, smooth and ecostate leaves, with plane, ribbonlike, flexuose-twisted leaf blades and heterogeneous laminal cells that are bulging or smooth, unistratose to partially bistratose in the distal part of the leaf and mostly rectangular at the margins near the base. Apart from Australasia, Murray (2006) reported this species from a number of widely separated regions in the southern hemisphere including New Guinea, Madagascar, southern Africa and South America, and in the northern hemisphere, from the Hawaiian Islands and Madeira in Macaronesia, but unfortunately, without giving specific localities or citations of specimens. The material from Madeira was recently recognised by Sérgio \& Sim-Sim (2012) as a separate subspecies, A. flexuosa ssp. luisieri Sérgio \& Sim-Sim.

When examining a collection of species of Andreaea Hedw. from the Falkland Islands, it became evident that the material reported from this archipelago as A. grimmioides Dusén (Cardot \& Brotherus, 1923) represents $A$. flexuosa, not $A$. flabellata Müll.Hal. as suggested by Matteri (1986). This is a noteworthy addition to the moss flora of the Falkland Islands, which is still not fully known. Matteri (2003) reported 146 species and ten infraspecific taxa from this archipelago, but since then several additions have been made (e.g. Allen \& Magill, 2003; Bednarek-Ochyra \& Ochyra, 2003; Blockeel et al., 2003; Ochyra \& Broughton, 2004; Ireland et al., 2005; Ochyra et al., 2015a), so the moss flora of the Falkland Islands consists at present of over 150 species.

\section{Barbilophozia floerkei (F.Weber \& D.Mohr)} Loeske

Contributors: B. Cykowska-Marzencka, M. Wegrzyn, P. Wietrzyk and M. Stryjak-Bogacka

Bolivia: Dept. La Paz, prov. Murillo, Cordillera Central, near Cumbre pass, $16^{\circ} 19^{\prime} 18^{\prime \prime} \mathrm{S}, 68^{\circ} 04^{\prime} 42^{\prime \prime} \mathrm{W}$, $4550 \mathrm{~m}$ a.s.1., on moist soil between the rocks and grass near the creek, 17 June 2006, leg. B. Cykowska-Marzencka 7201. (KRAM, LPB).

Svalbard: Spitsbergen, Nordenskiold Land, Bolterdalen, Rieperbreen glacier marginal zone: $78^{\circ}$ $7^{\prime} 30.14^{\prime \prime} \mathrm{N}, 16^{\circ} 2^{\prime} 54.12^{\prime \prime} \mathrm{E}, 275 \mathrm{~m}$ a.s.l., on immature soil on glacier moraine, 14 July 2015, leg. M. Wegrzyn s.n. (KRAM).

In Bolivia, Barbilophozia floerkei was found in very moist places by a very steep mountain stream, about 100 metres above the road from La Paz to Coroico. In Svalbard, B. floerkei was found during work on phytosociology and succession in glacier moraine communities of the Oscar II Land (Wegrzyn et al., 2013; Chrapusta et al., 2015; Węgrzyn \& Wietrzyk, 2015). The species was previously reported from Svalbard by Lindberg (1867), Berggren (1875), Arnell (1900), Hagen (1908), Arnell \& Mårtensson (1959), Boińska \& Gugnacka-Fiedor (1986) and Wegener et al. (1992), but later these records were questioned by Grolle (1960) and Frisvoll \& Elvebakk (1996), and the species was not included in the island's bryophyte checklist (Hodgetts, 2015).

Barbilophozia floerkei is a typical boreal-montane species with a subarctic range in the northern hemisphere. In Europe, the species is known from Ireland, Great Britain, Spain, France, Switzerland, Italy, Austria, Germany, the Czech Republic, Slovakia, Poland, Romania, Bulgaria, northern and central Russia and the Caucasus, Denmark, Sweden, 
Finland, Norway, Greenland and Iceland (Damsholt, 2002; Osyczka et al., 2007; Cykowska-Marzencka, 2013). Outside Europe, the species had been confirmed in Asia, from Siberia, Taimyr and the Chuchotskiy Peninsula and Japan (Furuki \& Mizutani, 1994; Damsholt, 2002). In North America it is recorded from Alaska to Washington and Montana, Colorado, New Mexico and in the east from Ellesmere Island to Vermont (Schuster, 1969). However, in South America the species is known only from high elevations in Peru (Grolle, 1960; Hässel de Menéndez \& Rubies, 2009) and this new locality in Bolivia, which is the second record for the continent. A report of $B$. floerkei from the subantarctic islands was considered erroneous by Grolle (2002) and it is not known why it was included in the later publication by Hässel de Menéndez \& Rubies (2009).

Recently, there have been many new bryophyte records for Bolivia (Blockeel et al., 2009, 2010; Ellis et al., 2012b, 2013a, 2014a, 2015c, 2016c; Cykowska, 2014), but despite a summary by Churchill et al. (2009), the Bolivian bryoflora still remains poorly understood and requires additional study. In Svalbard, the bryoflora appears to be better known. With the addition of $B$. floerkei and the recently discovered Odontoschisma sphagni (Dicks.) Dumort., (Hodgetts, 2015; Ellis et al., 2016c) the flora is now known to include 104 species of liverwort.

4. Barbilophozia hatcheri (Evans) Loeske

Contributors: Cs. Németh and J. Nagy

Hungary: Pest County, Buda Mountains [8579.2] (Central European Mapping Scheme), south of the village of Budakeszi, Mária-szurdok (on older maps known as either Meteor-szurdok or Kavics-árok), on shaded sandstone-conglomerate rock, $c a 252 \mathrm{~m}$ a.s.l., $47^{\circ} 29^{\prime} 39.3^{\prime \prime} \mathrm{N}, 18^{\circ} 55^{\prime} 43.1^{\prime \prime} \mathrm{E}, 10$ June 2016, leg. Cs. Németh, J. Nagy and G. Mészáros, det. Cs. Németh, conf. W. Schröder (Herb. Németh 7998). Associated bryophytes: Lophozia bicrenata (Hoffm.) Dumort., Marsupella funckii (F.Weber \& D.Mohr) Dumort., Scapania mucronata H.Buch, Dicranella heteromalla (Hedw.) Schimp., Dicranum scoparium Hedw., Hypnum cupressiforme Hedw., Polytrichum piliferum Schreb. ex Hedw.

Barbilophozia hatcheri is characterised by $3-4$ lobed leaves, the upper leaves having reddish gemmae at the tips of the lobes. Exact identification, however, needs microscopical examination of the cilia at the base of the leaves. In Hungary two other species of Barbilophozia occur, i.e. B. barbata (Schreb.) Loeske and B. floerkei (F.Weber \& D.Mohr) Loeske (Papp et al., 2010). The former differs from B. hatcheri in lacking cilia on the basal part of leaves, whilst the latter can be differentiated by the absence of gemmae and the shape of the cells of the cilia, which are subquadrate in the latter species, while they are elongated in $B$. hatcheri.

This calcifuge species usually grows on subneutral to acidic substrates. Its Hungarian habitat was on a shady northern steep slope, on sandstone-conglomerate rocks and on the soil between them.

In Europe, B. hatcheri is widely distributed and occurs in most European countries including all of those surrounding Hungary: Austria, Croatia, Romania, Serbia, Slovakia, Slovenia, Ukraine (Hodgetts, 2015). B. hatcheri is missing from the latest checklist for Hungary (Papp et al., 2010), and is new to the Hungarian bryoflora.

\section{Bryum chryseum Mitt.}

Contributors: J. Bruno Silva, S. Rangel Germano and N. Dias dos Santos

Brazil: Parque Nacional (PARNA) Vale do Catimbau, Pernambuco State, $08^{\circ} 35^{\prime} 03.3^{\prime \prime} \mathrm{S}, \quad 37^{\circ}$ $14^{\prime} 31.6^{\prime \prime} \mathrm{W}, 846 \mathrm{~m}$ a.s.1., on rock outcrop, 22 May 2014, leg. J.B. Silva 298 (UFP).

Bryum chryseum is a Neotropical species occurring in the USA (California), Mexico, Guatemala, Costa Rica, Panamá, Colombia, Peru, Bolivia, Brazil and Chile (Churchill \& Linares, 1995; Bordin \& Yano, 2009; Toren \& Heise, 2009). The first record in Brazil was from Rio Grande do Sul State (Bordin \& Yano, 2009). There, the species occurred on rock next to a remnant of humid forest. Herein, is the second record for Brazil. It occurred on an outcrop of rock in Caatinga (dry forest) vegetation in the Pernambuco State, PARNA Vale do Catimbau, more than $2500 \mathrm{~km}$ from the first Brazilian record. The discovery of this moss in northeastern Brazil represents a major eastward extension of its range. In spite of the hot semi-arid climate type (BSh'w) in the PARNA Catimbau, B. chryseum is a versatile moss species, and is known from dry and humid habitats (Ochi, 1980). It is also known from areas with a Mediterranean-type climate, e.g. California (USA) and Chile (Toren \& Heise, 2009).

In the field, growing in inconspicuous tufts, $B$. chryseum resembles Bryum argenteum Hedw. The important diagnostic characters of B. chryseum, the glossy shoots and imbricate leaves with hyaline awns at their apices, function as protection from intense solar radiation. Reliable taxonomic characters for the identification of this species include its possession of triangular-ovate leaves with recurved apices, quadrate alar cells and narrowly rhomboid cells in the upper lamina.

6. Bryum gemmiferum R.Wilczek \& Demaret

Contributor: G. Vončina

Poland: Western Carpathians, Kotlina OrawskoNowotarska basin, Huba village, Hubka hamlet, on the backwater of the Czorsztyn reservoir, $49^{\circ}$ $27^{\prime} 51^{\prime \prime} \mathrm{N}, 20^{\circ} 13^{\prime} 40^{\prime \prime} \mathrm{E}$, alt. $528 \mathrm{~m}$ a.s.l., on silt on the 
bank of the Dunajec river near the outlet into the reservoir, 8 November 2015, leg. \& det. G. Vončina, conf. A. Stebel (KRAM, SOSN).

Bryum gemmiferum occurred in small, scattered patches on sandy or muddy silt together with $B$. argenteum Hedw., B. dichotomum Hedw. and Funaria hygrometrica Hedw., and also on the sandy bank of a reservoir among Barbula unguiculata Hedw., Bryum argenteum, B. caespiticium Hedw., Calliergonella cuspidata (Hedw.) Loeske, Ceratodon purpureus (Hedw.) Brid., Funaria hygrometrica, Pohlia wahlenbergii (F.Weber \& D.Mohr) A.L.Andrews, Tortula acaulon (With.) R.H.Zander and a few species of vascular plants. Part of the locality is periodically inundated. The species is very easy to recognise in the field owing to the yellowish colouration of the plants and the presence of numerous minute gemmae in the axils of their leaves.

Since the species was described by Wilczek \& Demaret (1976), its occurrence has been reported in the United Kingdom, the Netherlands, Belgium and Lanzarote island, (Smith, 1978), Denmark, Germany, Portugal and Spain (Smith, 2004), Germany, Portugal and Spain and an uncertain record from Ireland (Düll, 1985). Hill et al. (1994) mapped its distribution within Great Britain and Ireland, and other records include Luxembourg (Werner, 1994), the Czech Republic (Soldán \& Kučera, 2004), Sweden (Hallingbäck et al., 2006), Balearics, Canary Islands, France, Spain, Portugal and Serbia (Ros et al., 2013), and Hungary (Erzberger \& Schröder, 2013). Records have also been published on-line: from Switzerland (Hofmann, 2014), Austria (Köckinger et al., 2016) and Norway (Moen, 2013). The species is also known from California and Florida in North America (Vanderpoorten \& Zartman, 2002). It is interesting that the overwhelming majority of its localities were discovered in the last decade.

7. Bryum klinggraeffii Schimp.

Contributors: C. Sérgio, D. Claro, J. Castillo Díaz and R. Gabriel

Portugal: Azores, Terceira Island, Praia da Vitória, Paul do Belo Jardim, $38^{\circ} 42^{\prime} \quad 49.30^{\prime \prime} \mathrm{N}, \quad 27^{\circ}$ $03^{\prime} 41.74^{\prime \prime} \mathrm{W}, 4 \mathrm{~m}$ a.s.1, on soil, associated with Leptophascum leptophyllum (Müll.Hal.) J.Guerra \& M.J.Cano and Barbula convoluta Hedw., 28 October 2013, leg. Javier Castillo Diaz 39 (AZU JCD_20131028/34; LISU 263359).

This is the first report of B. klinggraeffii for the Azores and Macaronesia. It is a widespread ephemeral colonist, Red Listed in some European countries (Hodgetts, 2015), and is probably overlooked and undercollected owing to its small size and the difficulties associated with the identification of some Bryum species.
Bryum klinggraeffii is a suboceanic species, more frequent in calcareous to slightly acid bare soils in arable fields, but can also occur along the margins of ponds and reservoirs. Dioicous, it can be recognised by its acuminate-lanceolate leaves with a denticulate apex, excurrent costa and by the presence of small rhizoidal gemmae $(60-100 \mu \mathrm{m}$ in diameter), which are red to dark brown, globose to pyriform, composed of irregularly aggregated cells, the exposed surfaces of the cells are convex (Crundwell \& Nyholm, 1964).

8. Bucklandiella didyma (Mont.) Bednarek-Ochyra \& Ochyra

Contributor: H. Bednarek-Ochyra

South Georgia: (1) near river draining into Undine Harbour, between Survey Isthmus and lower glacial plain Hope Valley, grid square GR 037 152, ca 54 $03^{\prime} 25^{\prime \prime} \mathrm{S}, 37^{\circ} 59^{\prime} \mathrm{W}$, in crevices of rock faces forming side of small gorge, 3 January 1961, leg. S. W. Greene 681 (AAS, KRAM); (2) north-facing scree slopes on south side of valley behind Right Whale Bay, grid square GR 053153 , ca $54^{\circ} 01^{\prime} 22^{\prime \prime} \mathrm{S}$, $37^{\circ} 43^{\prime} 01^{\prime \prime} \mathrm{W}$, ca $150 \mathrm{~m}$ a.s.1., on sheltered east-facing rock ledge, 6 January 1972, leg. B. G. Bell $416 \& 417$ (AAS, KRAM); (3) Royal Bay, rock outcrop on north side of Moltke Harbour, grid square GR 160 099 , ca $54^{\circ} 31^{\prime} 03^{\prime \prime} \mathrm{S}, 36^{\circ} 05^{\prime} 01^{\prime \prime} \mathrm{W}$, ca $15 \mathrm{~m}$, on very moist sheltered rock surface, 27 January 1972, leg. B. G. Bell 1363 (AAS, KRAM).

Bucklandiella Roiv. is a prominent moss genus in the bryoflora of South Georgia, both in terms of frequency and the number of species. So far, eight species of this genus have been recorded from this subantarctic island (Bell, 1974; Ochyra et al., 2002a; Bednarek-Ochyra \& Ochyra, 2012a). A ninth species, B. didyma, is herein added to the island's moss flora. The occurrence of this species was expected on the island and it was actually indicated on the global distribution map for this species (Ochyra et al., 2008a) and here it is substantiated by the citation of the relevant voucher collections. Bucklandiella didyma is the most common species of the genus in southern South America where it has a continuous range from the Archipelago Juan Fernández and the VII Región del Maule in central Chile at latitude $c a 35^{\circ} \mathrm{S}$ to Tierra del Fuego (Deguchi, 1984), with some isolated stations in Santa Catarina Province in SE Brazil (Bednarek-Ochyra et al., 1999) and in the Falkland Islands (Ochyra et al., 2015a). It extends to the northern maritime Antarctic where it is known from the South Sandwich Islands and the South Shetland Islands (Ochyra et al., 2008a, 2008b). Thus, the present records of $B$. didyma on South Georgia complete its distribution in the Scotia Arc and bridge its Fuegian and Antarctic localities. Bucklandiella didyma is a panholantarctic species, which is also known from South Africa (Ochyra et al., 2008a), SE 
Australia, Tasmania and New Zealand (BednarekOchyra et al., 2014).

Beside Heard Island, South Georgia is at present the most heavily glaciated of all subantarctic islands and most studies suggest that it was covered by a huge ice cap during the last glacial epoch (Graham et al., 2008). Nevertheless, the island was deglaciated relatively early and some palaeobotanical data clearly confirm the existence of ice-free refugia during the last glacial period (Van der Putten et al., 2004, 2009), so it is likely that some species of bryophytes, including $B$. didyma could have survived the glaciation in situ as is the case with other subantarctic (Van der Putten et al., 2010) and Antarctic islands (Birkenmajer et al., 1985). Considering the present record, as well as recent additions (Ochyra et al., 2002a; Blockeel et al., 2003, 2005, 2007), the moss flora of South Georgia consists of about 120 species and thus it has the second richest moss flora in subantarctica after Îles Kerguelen. Bucklandiella is the richest moss genus in the subantarctic, and only a few species are known from other islands in this biome, including B. ochracea (Müll.Hal.) BednarekOchyra \& Ochyra on Îles Kerguelen and Heard Island (Ellis et al., 2013d), B. membranacea (Mitt.) Bednarek-Ochyra \& Ochyra on Îles Crozet (Ellis et al., 2013c) and B. angustissima Bednarek-Ochyra \& Ochyra on Macquarie Island (Bednarek-Ochyra \& Ochyra, 2011). Interestingly, B. lamprocarpa (Müll.Hal.) Bednarek-Ochyra \& Ochyra has also not been recorded from South Georgia, although the species is common in southern South America (Ochyra et al., 1988, 2015a), in South Africa (Bednarek-Ochyra \& Ochyra, 2012b; Ochyra \& van Rooy, 2013) and is present on the subantarctic Îles Kerguelen (Bednarek-Ochyra \& Ochyra, 1998).

9. Campylium polygamum (Schimp.) Lange \& C.E.O.Jensen

Contributors: Y.-J. Yoon, H.-G. Choi and J. H. Kim Antarctica: South Shetland Islands, Nelson Island, Eco-Nelson Base, 62 $14^{\prime} 34^{\prime \prime} \mathrm{S}, 058^{\circ} 58^{\prime} 50^{\prime \prime} \mathrm{W}, 5 \mathrm{~m}$ a.s.1.; on wetland, 27 January 2016, leg. Y.-J. Yoon KG-2047 (KOPRI).

Campylium polygamum [三 Drepanocladus polygamus (Schimp.) Hedenäs] is here reported from Nelson Island. It is a bipolar species, infrequently distributed in the South Shetland Islands. To date, $C$. polygamum was known only from the Fildes and Byers Peninsula in the South Shetland Islands. This new record from Nelson Island is not surprising; nevertheless it expands the known range of the species in the Antarctic. In Nelson Island, C. polygamum occurred mainly in wet habitats at the margins of melt water channels. Previously, the species was found submerged to a depth of $9 \mathrm{~m}$ on Alexander Island and $10 \mathrm{~m}$ in Lake Kitezh on King George
Island (Ochyra et al., 2008a). Campylium polygamum can be distinguished from other species of Antarctic mosses by its short and double, or single costa, which extends up to $3 / 4$ of the leaf length.

10. Chionostomum hainanense B.C.Tan \& Y.Jia

Contributors: M. Suleiman and K.-T. Yong

Borneo: Sabah, Crocker Range Park, Tambunan District, Mount Alab, along park boundary, $1800 \mathrm{~m}$ a.s.l., on a bamboo trunk beside a small pond in a partially shaded area of a mossy forest, 9 September 2008, leg. M. Suleiman \& D. P. Masundang 3812 (BORH).

Chionostomum hainanense, in the Sematophyllaceae, was previously known only from China (Tan \& Jia, 1999) and Thailand (Printarakul et al., 2013). The leaves of this species are characterised by their heterophyllioid-type of alar organisation, the alar regions consist of a group of quadrate to rectangular cells, and the plants bear long cylindric capsules. The specimen from Borneo has all the characters of the species; however the mid-lamina cells are slightly longer, not markedly thick-walled and are less pitted than those in the type specimen (Tan \& Jia, 1999). Interestingly, the Sabah collection grew on a bamboo trunk, the same substrate as that of the type specimen from China. The species may be confused with members of the genus Gammiella Broth., but the latter genus is not reported for Borneo, and has much smaller plants, characterised by the presence of numerous filamentous propagules in their leaf axils. Chionostomum hainanense seems rare in Borneo. It has only been collected from Mount Alab, and was the only sample out of $c a 1400$ that were collected and studied during the preparation of a floristic report on Crocker Range Park.

11. Didymodon icmadophilus (Schimp. ex Müll.Hal.) K.Saito

Contributor: J. Kučera

Bulgaria: (1) Pirin Mts., Blagoevgrad Province, Bansko: on southern ridge of Mt Vihren $30 \mathrm{~m}$ above (NNW of) the saddle, $840 \mathrm{~m} \mathrm{~S}$ of the summit, $41.7598^{\circ} \mathrm{N}, 23.3979^{\circ} \mathrm{E}, 2600 \mathrm{~m}$ a.s.1., in fissure of calcareous schist rocks, 20 July 2010, leg. J. Kučera 13963 (CBFS); (2) Rhodope Mountains, Smolyan Province, Trigrad gorge: limestone rocks at the road $150 \mathrm{~m}$ below the lower entrance to 'Devil's Throat' cave, $41.6158^{\circ} \mathrm{N}, 24.3799^{\circ} \mathrm{E}$, ca $1170 \mathrm{~m}$ a.s.1., on accumulated soil in the fissures of limestone rocks, nearly unshaded, 23 July 2010, leg. J. Kučera 14024 (CBFS).

Macedonia: Šar Planina Mts., municipality of Tetovo, Popova Šapka, SE slopes of Mt Popova Šaka, $1.30 \mathrm{~km} \mathrm{~W}$ of the main parking lot, $42.0143^{\circ}$ $\mathrm{N}, 20.8662^{\circ} \mathrm{E}, 2050 \mathrm{~m}$ a.s.1., vertical unshaded face of a limestone rock in the slope, in small fissures, 14 July 2010, leg. J. Kučera 14024 (CBFS).

Didymodon icmadophilus is a taxonomically critical species which has recently been treated either as an independent species, closely related to D. acutus 
(Brid.) K.Saito (e.g., Hill et al., 2006; Jiménez, 2006), as the infraspecific taxon of the latter (Kučera, 2000) or even of D. rigidulus Hedw. (Zander, 2007). Molecular data (Werner et al., 2005; Kučera \& Ignatov, 2015) nevertheless support the independent origin of lineages matching D. icmadophilus, $D$. acutus, and D. rigidulus. Didymodon icmadophilus has been reported from mostly mountainous or northern regions of Europe, Asia, North, Central and South America, although the distribution details are obviously obscured by the difficult delimitation from similar taxa, particularly $D$. acutus and $D$. validus Limpr. In southern Europe, the species is only known from countries which include a part of the Alps (France, Italy, Slovenia; Ros et al., 2013) and from the Romanian Carpathians (Ştefănuț \& Goia, 2012). The presence of $D$. icmadophilus in the two higher mountain ranges of the Balkans (southern Dinaric Alps of Macedonia, Pirin of Bulgaria) is perhaps not very surprising, as numerous alpine species have been reported recently both from the Šar-Korab Mountains (e.g., Martinčič, 2009; Ellis et al., 2012b) and the high Bulgarian ranges, Rila and Pirin (e.g., Lüth, 2007; Natcheva, 2008). The area surrounding the Macedonian site yielded many alpine bryophyte species of sunny exposed base-rich rock outcrops (Grimmia alpestris (Schleich. ex F.Weber \& D.Mohr) Schleich., G. anodon Bruch \& Schimp., Hypnum vaucheri Lesq., Schistidium brunnescens Limpr., S. confertum (Funck) Bruch \& Schimp.), and a similar situation was observed at Mt Vihren in Bulgaria. At that site, accompanying species included Myurella julacea (Schwägr.) Schimp., Didymodon rigidulus Hedw., Gymnostomum aeruginosum Sm., Grimmia tergestina Tomm. ex Bruch \& Schimp., Schistidium brunnescens and others. Less expected was the occurrence of D. icmadophilus in the Trigrad Gorge in the Rhodopes, where the accompanying calciphilous bryoflora, although generally montane (e.g., Gymnostomum aeruginosum, Preissia quadrata (Scop.) Nees, Scapania aspera Bernet \& M.Bernet, Plagiopus oederianus (Sw.) H.A.Crum \& L.E.Anderson), was more thermophilous, without truly alpine elements, and even included Didymodon acutus and D. vinealis (Brid.) R.H.Zander, which I had never recorded with $D$. icmadophilus before. The identification of al reported specimens of $D$. icmadophilus was confirmed by molecular barcoding for the purpose of an ongoing study on the taxonomy of Didymodon sect. Didymodon.

12. Fossombronia caespitiformis subsp. multispira (Schiffn.) J.R.Bray \& D.C.Cargill

Contributors: S. Poponessi, M. Aleffi, D. Gigante and R. Venanzoni

Italy: Boschi di Ferretto-Bagnolo Umbria Region, Province of Perugia. It is a Site of Community
Importance $\quad(\mathrm{SCI}) \quad \mathrm{IT} 5210020, \quad 43^{\circ} 9.933^{\prime} \mathrm{N}, \quad 11^{\circ}$ $59.638^{\prime} \mathrm{E}$, ca $272 \mathrm{~m}$ a.s.l., on waterlogged soil with Isöetes histrix Bory, 24 April 2015, leg. \& det. S. Poponessi s.n. (PERU).

The investigations focused on a system of Mediterranean temporary ponds categorised as a priority habitat under the EU Directive 92/43/EEC and listed in Annexe I with the code 3170*.

According to Hodgetts (2015), this taxon is considered as Critically Endangered (CR) for Italy. Aleffi \& Schumacker (1995), cited by Hodgetts (2015) as the only source for the liverwort assessment, reported this taxon (sub Fossombronia husnotii Corb.) without any indication of the threat category.

The present report is the first for the subspecies $m u l$ tispira in Umbria, expanding its known distribution range to the NE, towards the inland territories of the Italian peninsula. In Italy, this taxon has a strictly Mediterranean distribution, located along the Tyrrhenian coasts (Aleffi et al., 2008). It has been found in very few, fragmented and scattered sites (Schwab, 1993, in litteris; Aleffi \& Carratello, 1998; Privitera \& Puglisi, 1999a, 1999b; Carratello, 2004; Cogoni et al., 2004; Preston \& Blockeel, 2006; Puglisi et al., 2006; Privitera \& Cenci, 2007). They highlight a clear connection with the fragile ecosystems of the Mediterranean temporary ponds, thus confirming the Critically Endangered assessment indicated by Hodgetts (2015).

The species is monoecious and often fertile, with spores ripening mainly from late summer or autumn to spring, and it has been assigned to the TropicalTemperate phytogeographical element (Dierßen, 2001). The distribution range is still poorly known because its taxonomy has only recently been clarified (Lockhart et al., 2012). Two subspecies (F. caespitiformis subsp. multispira and F. caespitiformis subsp. caespitiformis) occur in nearly all of the Mediterranean countries, and in Madeira and the Canary Islands (Ros et al., 2007). Only F. caespitiformis subsp. multispira has been reported further north in W Europe, with recent records confirmed by the studies of elaters of the two subspecies from Ireland, SW England and Belgium (Lockhart et al., 2012). Records of $F$. caespitiformis s.l. from Africa, SW Asia and Australia need to be reassessed to establish which subspecies are involved (Lockhart et al., 2012). Its presence in the Italian peninsula has only recently been confirmed, in Tuscany, Lazio, Campania, Calabria and Sardinia and Sicily (Aleffi et al., 2008).

13. Hedwigia striata (Wilson) Bosw.

Contributors: M. Infante and P. Heras

France: Lot, Cornac, river Mamoul, $1 \mathrm{~km}$ to the East of Souilhol. $44.90611^{\circ} \mathrm{N}, 1.91999^{\circ} \mathrm{E} ; 277 \mathrm{~m}$ a.s.1., saxicolous on the most exposed part of a rocky 
gneiss outcrop, 5 June 2013, leg. M. Infante \& P. Heras, BBF bryo $376 / 13$.

Hedwigia striata was reinstated at the rank of species by Buchbender et al. (2014). The distribution area given in this publication was improved in Hespanhol et al. (2013) and Gallego et al. (2014). It includes the Iberian Peninsula to the south, and Belgium, Great Britain and Scandinavia to the north. The expected finding of $H$. striata in France fills the distribution gap between these regions. The French locality matches the general ecology of the species, saxicolous on siliceous rock surfaces, in a community dominated by Hypnum cupressiforme Hedw. var. cupressiforme and Frullania tamarisci (L.) Dumort., also with the presence of Grimmia hartmanii Schimp. and G. trichophylla Grev.

14. Isopterygium byssobolax (Müll.Hal.) Paris

Contributors: G. F. P. Bojaca, L. B. Fantecelle, C. A. T. Araújo and A. S. Maciel-Silva

Brazil: Estação Ecológica da Universidade Federal de Minas Gerais, Belo Horizonte, Minas Gerais, $19^{\circ}$ $52^{\prime} 34^{\prime \prime} \mathrm{S}, 43^{\circ} 58^{\prime} 21^{\prime \prime} \mathrm{W}, 813 \mathrm{~m}$ a.s.l., on tree trunk base, 3 May 2014, leg. Maciel-Silva, A. S. 291 (BHCB N ${ }^{\circ}$ 175342).

Isoterygium byssobolax is one of the smallest species of Isopteryium in Latin America (Ireland \& Buck, 2009), occurring in Brazil, Bolivia, Paraguay and Argentina. In Brazil, it occurs in the states of Rondônia, Mato Grosso, Espírito Santo, São Paulo, Paraná, Rio Grande do Sul and Santa Catarina, including the phytogeographic domains of Amazonia, Cerrado and Atlantic Forest (Peralta, 2016). During a bryophyte survey of the Ecological Station of the Federal University of Minas Gerais, an important urban reserve of Cerrado and semideciduous forest in the municipality of Belo Horizonte, we collected I. byssobolax with mature sporophytes. This is the first record of I. byssobolax for the state of Minas Gerais. This report extends its distribution in Brazil, $>400 \mathrm{~km}$ from the other records, and corroborates its distribution in southeastern South America. The Ecological Station of UFMG preserves a significant number of species in a 14 ha area, contributing to maintain ecosystems services, and for development of research studies and environmental education courses (Antonini \& Martins, 2003; UFMG, 2015). Isoterygium byssobolax is usually found in forests on rotten wood and tree bases up to $1180 \mathrm{~m}$ a.s.1.; it is recognised by: (1) small gametophyte size (stems reach $1.3 \mathrm{~cm}$ long, $0.5-1 \mathrm{~mm}$ wide; (2) leaves $(<1 \mathrm{~mm}$ long) that are ovate to ovate-lanceolate, concave and acuminate, with a distinct alar region of 2-4 rows of quadrate cells, totalling 4-10 cells; (3) sporophytes with setae $0.6-1 \mathrm{~cm}$ long and ovoid to ellipsoid capsules (Ireland, 1992; Ireland \& Buck, 2009).
15. Leptobryum pyriforme (Hedw.) Wilson

Contributors: H. Bednarek-Ochyra and V. Plášek

Chile: XI Región Aysén del General Carlos Ibáñez del Campo, Provincia de General Carrera: $32 \mathrm{~km}$ west of Villa Cerro Castillo on Río Cajón, in grassland at the wayside of Carretera Austral-Ruta 7, $46^{\circ}$ $07^{\prime} 535^{\prime \prime} \mathrm{S}, 72^{\circ} 33^{\prime} 605^{\prime \prime} \mathrm{W}, 414 \mathrm{~m}$ a.s.1., on spots of bare clay soil in an open and insolated site at the roadside, 16 January 2015, leg. H. Bednarek-Ochyra, R. Ochyra \& V. Plášek 574/15 (KRAM, SGO).

Leptobryum pyriforme is widely distributed but scattered in most regions of Chile, from IV Región Limari in the north to XII Región Magallanes in the south (Müller, 2009). In XI Región Aysén it has hitherto been recorded from Provincia de Aisén, Provincia de Coyhaique and Provincia de Capitán Prat (Ellis et al., 2015c) and here it is reported from Provincia de General Carrera in the southern part of this Región. Outside mainland southern South America L. pyriforme is known from the Falkland Islands (Ellis et al., 2015b), subantarctic South Georgia (Ochyra et al., 2002a) and two stations in the maritime Antarctic (Blockeel et al., 2006b; Ochyra et al., 2008a).

16. Neckeropsis foveolata (Mitt.) Broth.

Contributor: J. Enroth

Guinea: 'Près de Macenta. Forêt dense' 24 April 1963, leg. S. Lisowski 20501 (KRAM). 'Région de Macenta. Massif du Ziama, près de Zoubrouma. Forêt dense. Epiphyte.' 30 December 1962, leg. S. Lisowski 4192 (KRAM). 'Région de Macenta. Massif du Ziama, près de Zoubrouma. Forêt dense. Epiphyte.' 22 May 1962, leg. S. Lisowski 600 (KRAM). 'Région de Macenta, près de Zoubrouma. Plantation de Cola nitida. Epiphyte.' 13 January 1963, leg. S. Lisowski 168 (KRAM). 'Région de Macenta. Massif du Ziama, près de Seredou. Forêt dense.' 12 February 1962, leg. S. Lisowski 2628 (KRAM). 'Près de Macenta. Plantation de café. Epiphyte.' 25 January 1962, leg. S. Lisowski 723 (KRAM). 'Région de Macenta. Epiphyte sur un arbre de café dans une plantation au $\mathrm{S}$ de Macenta, ca 650 m', 25 January 1962, leg. S. Lisowski 421 (H, KRAM). 'Près de Macenta. Rochers, dans la forêt secondaire', 25 January 1962, leg. S. Lisowski 163 (KRAM). 'Région de Macenta. Massif du Ziama, au-dessus du Poste 5. Forêt de montagne. Epiphyte', 17 December 1962, leg. S. Lisowski $111(\mathrm{H}$, KRAM). 'Près de Macenta. Env. $750 \mathrm{~m}$. Forêt dense. Epiphyte', 22 May 1962, leg. S. Lisowski 4686 (KRAM). 'Près de Macenta. Plantation de café. Epiphyte.' 28 January 1962, leg. S. Lisowski 277 (KRAM).

Neckeropsis foveolata is a Neotropical-African species. In Africa it is known from Liberia, Nigeria, Central African Republic and Democratic Republic of the Congo (Enroth, 1993). The Guinean collections 
by Lisowski came from the vicinity of the town of Macenta in SE Guinea, several of them from the now protected Ziama Massif forests.

Due to its deeply undulate leaves, $N$. foveolata can in Africa be confused with $N$. lepineana (Mont.) M.Fleisch., but the latter has a very weak and short costa, while $N$. foveolata has a strong, single costa reaching well above midleaf (Enroth, 1993).

17. Neckeropsis spuriotruncata (Dusén) M.Fleisch.

Contributor: J. Enroth

Guinea: 'Près de Macenta. Galerie forestière. Epiphyte' 27 March 1963, leg. S. Lisowski 74 (KRAM). 'Près de Macenta. Forêt dense' 13 May 1962, leg. S. Lisowski 3888 (KRAM). 'Près de Macenta. Forêt dense. Epiphyte sur tronc d'un arbre au bord d'un torrent' 25 January 1962, leg. S. Lisowski 571 (KRAM). 'Région de Macenta. Galerie forestière au bord de la Loffa, près de la route Macenta-Nzerekore. Epiphyte', 3 February 1963, leg. S. Lisowski 4511 (KRAM), 166 (H, KRAM).

Democratic Republic of the Congo: 'République du Zaire, Haut-Zaire, $20 \mathrm{~km}$ au NW de Kisangani. Bord de la Lindi'. 24 January 1973, leg. S. Lisowski 5830 (KRAM). 'République du Zaire, Haut-Zaire, $34 \mathrm{~km}$ au $\mathrm{N}$ de Kisangani, près du village Bambayo. Rochers au bord de la Lindi', 26 June 1977, leg. S. Lisowski 50520 (KRAM).

This is a rare West African species, previously known from Ivory Coast, Cameroon, Gabon and Republic of the Congo (Enroth, 1993). It is morphologically close to, but consistently distinguishable from, N. liliana (Renauld) Broth. and N. madecassa (Besch.) M.Fleisch., both of which are known from the same areas in Africa, and the latter also from Madagascar and Réunion. Neckeropsis spuriotruncata grows on rocks and tree trunks and, according to Potier de la Varde (1936), also on tree stumps.

\section{Orthothecium strictum Lorentz}

Contributors: M. J. Cano and L. Hedenäs

Spain: Barcelona, Berguedà, Creu de Peguera, $48^{\circ}$ $08^{\prime} \mathrm{N}, 01^{\circ} 46^{\prime} \mathrm{E}, 12$ August 1973, leg. Vives s.n. (BCB 50198).

During the revision of the genus Orthothecium Schimp., as part of the project 'Flora Briofítica Ibérica,' the first author found a specimen deposited in the herbarium $\mathrm{BCB}$, which exhibits the characters of $O$. strictum, a species that was not previously reported from Spain. The sample is rather scanty and grew in a locality with $O$. intricatum (Hartm.) Schimp. Some of this specimen was sent to the second author, who confirmed the material as $O$. strictum.

Orthothecium strictum is an Arctic and northern mountainous species, that is found rarely in mountains further south in Europe, North America and Asia (Ignatov et al., 1996). In addition, it occurs in New
Zealand (Beever et al., 1992). In the Mediterranean area, it has only been reported from the French Pyrenees (v. gr. Husnot, 1884-1890, Augier, 1966) and the French and Italian Alps (Augier, 1966; Skrzypczak \& Skrzypczak, 2000; Cortini Pedrotti, 2001). The species is recognised by its small size, leaves slightly longitudinally plicate, with recurved and distally denticulate margins, and relatively short leaf lamina cells. The specimen was collected in the protected area Serra d'Ensija-Rasos de Peguera, a calcareous zone belonging to pre-Pyrenean ranges of Catalonia. It was collected at $c a 1900 \mathrm{~m}$ elevation, although this is not indicated on the label. This collection represents the first record of this species in the Iberian Peninsula.

19. Orthotrichum bistratosum (Schiffn.) J.Guerra

Contributors: T. Kiebacher and M. Lüth

Greece: Epirus, Ioannina, Monodendri, at the viewpoint Oxia, $39^{\circ} 54^{\prime} 23^{\prime \prime} \mathrm{N}, 20^{\circ} 45^{\prime} 05^{\prime \prime} \mathrm{E}, 1280 \mathrm{~m}$ a.s.1., rock slope, on limestone, together with Grimmia tergestina Bruch \& Schimp., 06 June 2015, leg. T. Kiebacher \& M. Lüth s.n. (priv. herb. T. Kiebacher).

Orthotrichum bistratosum was originally described from Syria as Orthotrichum cupulatum var. bistratosum Schiffn. (Schiffner, 1913). Lara \& Garilleti (2014), in agreement with Guerra (1985), consider the taxon to be a distinct species. Today $O$. bistratosum is known from the Middle East (Iraq, Israel, Syria and Turkey) and from the Mediterranean (France and Spain) (Ellis et al., 2010; Ros et al., 2013; Lara \& Garilleti, 2014). Orthotrichum bistratosum differs from $O$. cupulatum Brid. in gametophytic as well as sporophytic characteristics. The most striking difference is the extensively bistratose leaf lamina. The prostome, which is typically well developed in $O$. cupulatum, is rarely present, or low and discontinuous, in $O$. bistratosum. Furthermore, the leaves of $O$. bistratosum are smooth or almost smooth, whereas in $O$. cupulatum they are usually distinctly papillose. In the field $O$. bistratosum may be distinguished from $O$. cupulatum by the blackish colour and the large perichaetial leaves which often completely hide the capsules (Lara \& Garilleti, 2014). However, these characteristics can also occur in $O$. cupulatum and the two species can also grow together (Ellis et al., 2010).

At the locality where $O$. bistratosum has been found in Greece it was associated with $G$. tergestina. Several tufts grew on exposed calcareous rocks that are known to be the typical habitat of the species. More rarely the species has also been found growing on siliceous rocks or on the bark of trees (Lara \& Garilleti, 2014). This record indicates that the $O$. bistratosum probably also occurs in other Mediterranean countries.

20. Orthotrichum crenulatum Mitt. 
Contributors: V. Plášek, A. Nowak and M. Nobis

Georgia: $46 \mathrm{~km}$ E of Tbilisi city, SE edge of Giorgitsminda town, along a road, on bark of wayside tree (Fraxinus excelsior L.), GPS coordinates (WGS 84): $41^{\circ} 43^{\prime} 00.2^{\prime \prime} \mathrm{N}, 4^{\circ} 21^{\prime} 29.6^{\prime \prime} \mathrm{E}$, ca $630 \mathrm{~m}$ a.s.1., 27 April 2015, leg. A. Nowak \& M. Nobis s.n., det. V. Plášek (OSTR \#B1549).

To date, 16 taxa of the broadly interpreted genus Orthotrichum Hedw. have been reported from Georgia (Chikovani \& Svanidze, 2004; Ignatov et al., 2006; Kürschner et al., 2013) and $O$. crenulatum is a new addition to the bryoflora of the country. This epiphytic moss was considered to be endemic to the area around north-eastern Afghanistan, northern India, western Tibet, Turkestan and Kazakhstan (Lewinsky, 1992). However, subsequently it was recorded also from other countries in Central Asia, including Pakistan (Schäfer-Verwimp \& Gruber, 2002), Tajikistan (Ellis et al., 2011) and Kyrgyzstan (Ellis et al., 2014b). In 1991 it was found for the first time outside Asia, in France in Europe (Boudier \& Pierrot, 1992 as $O$. flowersii Vitt).

In Georgia, $O$. crenulatum was first collected in 2015, during a Polish botanical expedition, on the bark of Fraxinus excelsior which was planted in the alley alongside the road-verge within the city of Giorgitsminda. It was found growing together with $O$. anomalum Hedw., $O$. diaphanum Brid. and $O$. pumilum Sw. and the moss produced sporophytes in profusion.

Orthotrichum crenulatum is closely related to $O$. pamiricum Plášek \& Sawicki which was recently described as a new species from the western foothills of the Pamir Mountains of the Tajik-Afghan border in Central Asia (Plášek et al., 2014). Orthotrichum pamiricum is similar to $O$. crenulatum in gametophyte characters, including an obtuse and crenulate leaf apex, but it can be easily distinguished from the latter mainly by the 16 (papillate) endostome segments. Moreover, O. pamiricum has stomata arranged in 2 rows in the upper part of the capsule, whereas in $O$. crenulatum they are concentrated in the median part of the urn. In addition, a prostome was observed in $O$. pamiricum, which is absent from $O$. crenulatum. At the base of the endostome segments short rudimentary appendages sometimes occur in $O$. pamiricum but this would not lead to confusion with $O$. moravicum which was recently also reported from Central Asia (cf. Plášek et al., 2009; Ellis et al., 2012b).

\section{Orthotrichum philiberti Venturi}

Contributors: M. Kirmaci and E. Agcagil

Turkey: Province Aydın, Samsun Mountain, Bademlik locality, $37^{\circ} 39^{\prime} 51.0^{\prime \prime} \mathrm{N}, \quad 27^{\circ} 0.2^{\prime} 52.0^{\prime \prime} \mathrm{E}$, $140 \mathrm{~m}$ a.s.1., epiphytic on Quercus cercis L. with Orthotrichum diaphanum Schrad. ex Brid., O. affine Schrad. ex Brid. and Syntrichia montana Nees, 27
December 2012, leg. and det. M. Kirmaci \& E. Agcagil EMA 889, confirmed A. Erdağ. East of Güzelçaml, Pinus brutia Ten., Quercus ilex L. and Q. cerris mixed forest, $37^{\circ} 41^{\prime} 06.2^{\prime \prime} \mathrm{N}, 27^{\circ} 15^{\prime} 36.1^{\prime \prime} \mathrm{E}$, $415 \mathrm{~m}$ a.s.1., epiphytic on $Q$. ilex, associated with Hypnum cupressiforme Hedw., 12 April 2013, leg. and det. M. Kirmacı \& E. Agcagil EMA 1165.

Orthotrichum Hedw. is the richest moss genus in Turkey and the countries of Europe, with 38 taxa (34 species and 4 varietes including $O$. rupestre Schwägr. var. kurdicum Schiffn.) (Ros et al., 2013; Ellis et al., 2015a). The new record, O. philiberti, raises to 39 the number of Orthotrichum taxa known from Turkey. In the last decade many new additions belonging to this genus have been added to the Turkish bryoflora (Ellis et al., 2010, 2015a; Lara et al., 2010). One of the most important reasons for this richness is that Turkey is very well endowed with tree species [630 naturally occurring taxa (Akkemik, 2014)], some of which are especially important for epiphytic bryophytes. Orthotrichum philiberti was collected on two different species of Quercus L., which with 24 taxa, is the most important genus in the Turkish flora (Akkemik, 2014). Species of Quercus are dispersed all around the country, and are especially important for bryophytes owing to the surface of their bark.

The features of our specimen fully match those described for $O$. philibertii. This species differs from O. alpestre Bruch \& Schimp., O. pallens Bruch ex Brid., O. pumilum Sw. and O. schimperi Hammar by its oblong lanceolate mucronate leaves and thin pale calyptra with thick papillose hairs. It is not surprising that $O$. philibertii should be found in Turkey, as it is very common in Mediterranean countries (Ros et al., 2013). According to Blockeel et al. (2006c), O. philiberti prefers a mild climate and oceanicMediterranean environments. These Turkish collections were from the northern part of Samsun Mountain which has a Mediterranean climate and is influenced by sea moisture.

22. Orthotrichum tanganyikae (P.de la Varde) Q.H.Wang \& Y.Jia

Contributors: J. A. Calleja, R. Garilleti, V. Mazimpaka, B. Vigalondo and F. Lara

Kenya: Mt Kenya, supra Shipton's camp, rock fields in front of Peter Point, $00^{\circ} 08^{\prime} 35^{\prime \prime} \mathrm{S}, 037^{\circ} 18^{\prime} 23^{\prime \prime} \mathrm{E}$, $4600 \mathrm{~m}$ a.s.1, basalt outcrops with scattered afroalpine vegetation, in crevices of basaltic rocks, 14 August 2014, leg. F. Lara 1408/12 (with R. Garilleti, B. Vigalondo \& J. A. Calleja) (MAUAM 4593, BCB 58437, VAL-Briof 11636); ibidem, $4460 \mathrm{~m}$ a.s.1., in crevices of basaltic rocks, 14 August 2014, leg. F. Lara 1408/14 (with R. Garilleti, B. Vigalondo \& J. A. Calleja), (MAUAM 4843); ibidem, Shipton's camp surroundings, $00^{\circ} 08^{\prime} 29^{\prime \prime} \mathrm{S}, \quad 037^{\circ} 18^{\prime} 54^{\prime \prime} \mathrm{E}$, $4200 \mathrm{~m}$, afroalpine vegetation dominated by 
Dendrosenecio sp. pl. trees, on basalt rock wall, 14 August 2014, leg. J. A. Calleja, F. Lara, R. Garilleti \& B. Vigalondo s.n. (MAUAM 4844, BCB 58438, VAL-Briof 11637); ibidem, Lenana Peak, 0009'19"S, $037^{\circ} 19^{\prime} 02^{\prime \prime} \mathrm{E}, 4860 \mathrm{~m}$, basalt rock crevices, 15 August 2014, leg. F. Lara 1408/21 (with R. Garilleti, B. Vigalondo \& J. A. Calleja) (MAUAM 4845); ibidem, $4900 \mathrm{~m}$, basalt rock crevices, 15 August 2014, leg. F. Lara 1408/20 (with R. Garilleti, B. Vigalondo \& J. A. Calleja) (MAUAM 4846, BCB 58439, VAL-Briof 11638); ibidem, Lenana peak to Mintos camp trail, $00^{\circ} 08^{\prime} 56^{\prime \prime} \mathrm{S}, 037^{\circ} 19^{\prime} 19^{\prime \prime} \mathrm{E}, 4630 \mathrm{~m}$, basalt rock crevices, 15 August 2014, leg. J. A. Calleja, F. Lara, R. Garilleti \& B. Vigalondo s.n. (MAUAM 4847, BCB 58440, VAL-Briof 11639).

Tanzania: Mt Kilimanjaro, Lava Tower surroundings, $03^{\circ} 03^{\prime} 58^{\prime \prime} \mathrm{S}, 037^{\circ} 19^{\prime} 26^{\prime \prime} \mathrm{E}, 4580 \mathrm{~m}$, afroalpine rocky semi-desert, on an isolated basalt boulder, 22 August 2014, leg. J. A. Calleja, F. Lara, R. Garilleti \& B. Vigalondo s.n. (MAUAM 4851, BCB 58441, VAL-Briof 11640); ibidem, $4640 \mathrm{~m}$ a.s.1., basalt outcrop area, in boulder crevices, 22 August 2014, leg. F. Lara 1408/41 (with R. Garilleti, B. Vigalondo \& J. A. Calleja) (MAUAM 4852, BCB 58442, VAL-Briof 11.641).

Ulota tanganyikae was described by Potier de la Varde (1955) from a unique locality, found in 1948 in the highlands of Mount Kilimanjaro; there had been no subsequent records. A single herbarium specimen of that original record is available in PC! Recently, Wang \& Jia (2014) reinterpreted the taxon as a member of the genus Orthotrichum Hedw., and after comparison with other African Orthotrichum species, they also placed $O$. oreophilum Lewinsky \& van Rooy, from Leshoto (Lewinsky \& van Rooy, 1990), in synonymy with $O$. tanganyikae.

Orthotrichum tanganyikae is currently known only from that single Tanzanian locality (Potier de la Varde, 1955) and four close sites in the South African Drakensberg Mountains (Lewinsky \& van Rooy, 1990). It seems to be a saxicolous species that inhabits sheltered microhabitats within volcanic environments above $3000 \mathrm{~m}$ a.s.l. Our recent gatherings in East Africa confirm and expand the available information on its distribution and habitat preferences.

On Mt Kenya, from where $O$. tanganyikae is reported here for the first time, it is fairly common in the summit area, between 4200 and $4900 \mathrm{~m}$ a.s.1. It usually occurs in basalt rocky niches (under basalt boulders, in crevices or on vertical walls) that buffer the strong insolation and dry winds commonly affecting the afroalpine ecosystems. The species grows in areas of afroalpine vegetation dominated by giant trees of Dendrosenecio keniodendron (R.E.Fr. \& T.C.E.Fr.) B.Nord., but it also lives in zones with scattered cushion-like scrubs and herbs due to the harsh environmental conditions of higher altitudes (Bussmann, 2006). Orthotrichum tanganyikae has been frequently found along with $O$. rupestre Schwägr., growing on the same outcrop microhabitats (walls and crevices). However, O. tanganyikae has never been observed growing as an epiphyte, yet on Mt Kenya it occurs in some places where other Orthotrichum species (including $O$. rupestre) thrive on shrub branches or Dendrosenecio trunks.

On Mt Kilimanjaro, O. tanganyikae has been newly recorded in only one locality on the western slope of the Kibo Peak. This second locality is $c a 15 \mathrm{~km}$ from the previously known type locality of the species, on the western slopes of Mawenzi Peak. Within the new locality the species is relatively abundant in a narrow altitudinal range, from 4580 to $4640 \mathrm{~m}$ a.s.1., and immersed in the altodesertic vegetation belt (Bussmann, 2006). It mainly occurs on the northern walls of lava towers and in boulder crevices, but it could not be found in neighbouring areas with similar environmental characteristics.

\section{Pelekium scabrosulum (Mitt.) Touw}

Contributors: N. Norhazrina and A. Vanderpoorten Martinique: Northern side of the Montagne Pelée, track between Anse Couleuvre and Cascade Couleuvre, $14^{\circ} 50^{\prime} \mathrm{N}, 60^{\circ} 12^{\prime} \mathrm{W}$, ca $100 \mathrm{~m}$ a.s.l., epiphytic within moist lowland rainforest in a ravine, with Neckeropsis disticha (Hedw.) Kindb., 1 April 2016, leg. A. Vanderpoorten MARl (LG).

The species, which is widespread across the Neotropics, is new to Martinique (Lavocat Bernarda \& Schäfer-Verwimp, 2011). It is readily distinguished from Thuidium tomentosum Schimp., which is very abundant on wet ground and on rocks within the ravine in the area, by its papillose seta and nonbranched paraphyllia. It differs from Pelekium investe (Mitt.) Touw, which was the only Pelekium species reported from Martinique, by its regular bipinnate branching pattern. It also differs from $P$. schistocalyx (Müll.Hal.) Touw, which was recently reported from Guadeloupe (Lavocat Bernarda \& Schäfer-Verwimp, 2011), by its longly acuminate, but not ciliate perichaetial leaves, its 3-5-cell long pseudoparaphyllia, and its spreading leaves in the dry state, leaving the stems clearly visible (Buck, 2003).

24. Physcomitrella patens (Hedw.) Bruch \& Schimp.

Contributor: C. Sérgio and C. A. Garcia

Portugal: (1) Beira Litoral, Aveiro, Oliveira do Bairro, $40^{\circ} 32^{\prime} 52.99^{\prime \prime} \mathrm{N}, 8^{\circ} 29^{\prime} 56.63^{\prime \prime} \mathrm{W}, 24 \mathrm{~m}$ a.s.1., wet soil, along a waterline and around a pond, with Ptychostomum donianum (Grev.) Holyoak \& N.Pedersen, 16 November 2013, leg. C. Sérgio s.n. (LISU 262262); (2) Estremadura, Vila Franca de Xira, Companhia das Lezírias, $38^{\circ} 50^{\prime} 23.30^{\prime \prime} \mathrm{N}, 8^{\circ}$ $58^{\prime} 37.04^{\prime \prime} \mathrm{W}, 2 \mathrm{~m}$ a.s.1., on open saline soil, included in Phragmites Adans. community with Tortula 
truncata (Hedw.) Mitt. and Entosthodon hungaricus (Boros) Loeske, 8 October 2013, leg. C. Sérgio s.n. (LISU 262265).

During recent field studies in central Portugal two specimens of Physcomitrella patens were collected. They represent the first records of this species for Portugal, since, despite $P$. patens having been already reported in Flora Briofítica Ibérica (Guerra et al., 2010) based on a sample gathered in the Algarve by Ron Porley, it was later confirmed that this specimen belonged to $P$. readeri (Müll.Hal.) I.G.Stone \& G.A.M.Scott (Ellis et al., 2012b).

The overall appearance of the two species is similar in the field, although $P$. patens can be recognised by its spathulate or obovate leaves with a characteristically long costa that extends up to the leaf apex. In $P$. readeri the costa is less well differentiated and only reaches the middle of the leaf. The two species are morphologically very similar, the leaves have a short apiculus and the margins are entire near the base, serrate in the distal third.

The new discoveries of $P$. readeri and $P$. patens in Portugal may indicate that this genus is probably expanding its range. $P$. readeri was found last year in two new localities (Estremadura in Serra de Sintra in Barragem da Mula and Ribatejo near Coruche).

Physcomitrella patens is very well known by the scientific community and numerous researchers use it as a model organism in ecophysiology studies (Glime, 2015). The fully mapped genotype of this species is a resource for understanding gene functioning as well as for implementing different experimental methods of research in plant biology (Rensing et al., 2008; von Schwartzenberg, 2009; Beike \& Rensing, 2010).

25. Pohlia cruda (Hedw.) Lindb.

Contributors: H. Bednarek-Ochyra and M. Lebouvier

Îles Crozet, Île de la Possession: eastern coast, Pointe Lieutard, rock outcrops $300 \mathrm{~m}$ south of Alfred Faure Station, $\quad 51^{\circ} 51.513^{\prime} \mathrm{E}, \quad 46^{\circ} 26.132^{\prime} \mathrm{S}, \quad 100 \mathrm{~m}$ a.s.1., forming small tufts under overhanging rock in shaded and dry situations, 16 November 2012, leg. R. Ochyra 2657/ 12 (KRAM).

In the southern polar regions Pohlia cruda is widespread and locally abundant in the maritime Antarctic (Ochyra et al., 2008a) and in the Subantarctic it is frequent on South Georgia (Clarke, 1973) and occasional in Îles Kerguelen (Brotherus, 1906). Here, its range is extended to Îles Crozet where it was found on Île de la Possession. This is a noteworthy addition to the moss flora of this archipelago, which is the least studied bryologically of all subantarctic islands. However, recent field studies yielded a number of new additions to the moss flora of the archipelago (e.g. Blockeel et al., 2006a; Ellis et al., 2012c, 2013b, 2014c, 2015a, 2015b; Ochyra \& Bednarek-Ochyra, 2013; Ochyra et al., 2015b) and as a result the moss flora of Îles Crozet consists at present of over 70 species. This is still the lowest number of species in comparison with the moss floras of the adjacent archipelagoes of the Prince Edward Islands and Îles Kerguelen. Pohlia cruda has a pantemperate distribution in the southern hemisphere and its range covers southern South America, Lesotho in South Africa and SE Australia, Tasmania and New Zealand with some offshore islands (Ochyra et al., 2008a). Pohlia cruda is a bipolar species with some intermediate stations in the northern Andes and recently it was also discovered in East Africa (Blockeel et al., 2007; Ellis et al., 2016a).

26. Pseudocalliergon lycopodioides (Brid.) Hedenäs

Contributors: A. Koczur and M. Hájek

Poland, Western Carpathians, Kotlina OrawskoNowotarska: 'Puścizna Rękowiańska' fen near Czarny Dunajec, $49^{\circ} 27^{\prime} 51^{\prime \prime} \mathrm{N}, 1^{\circ} 51^{\prime} 04^{\prime \prime} \mathrm{E}, 652 \mathrm{~m}$ a.s.1, wet depressions in eastern part of the fen, 7 October 2010, leg. A. Koczur s.n., det. M. Hajek, conf. R. Ochyra (KRAM); 3 October 2014, leg. and det. P. Hájková s.n. (BRNU).

This is the first recently confirmed record of Pseudocalliergon lycopodioides in the Western Carpathians. Until now, the species was not known from the Polish and Czech parts of the Carpathians (Żarnowiec et al., 2004; Kučera, 2005). Pseudocalliergon lycopodioides had been recorded many times from the Slovak part of the Carpathians, but all records were based on misidentifications (Pilous, 1991). Nevertheless, it has occurred in the Záhorská nížina lowland close to the south-western margin of the Western Carpathains (the Malé Karpaty Mts), the last collection being from 1997 (Janovicová \& Kubinská, 2002). In the Puścizna Reckowiańska fens the species grows semi-aquatically along with $P$. trifarium (F.Weber \& D.Mohr) Loeske and Scorpidium scorpioides (Hedw.) Limpr. on abandoned post-exploited areas undergoing natural succession, in wet depressions surrounded by fen vegetation with Limprichtia cossonii (Schimp.) L.E.Anderson, H.A.Crum \& W.R.Buck., Campyllium stellatum (Hedw.) Lange \& C.E.O.Jensen, Hamatocaulis vernicosus (Mitt.) Hedenäs, Fissidens adianthoides Hedw. and other species. Long-term observations from 1998 to the present (our unpublished data) has shown no fluctuation in species abundance or environmental conditions.

27. Radula mammosa Spruce

Contributor: A. Schäfer-Verwimp

Costa Rica: Provincia de San José, Cordillera de Talamanca, San Gerardo de Dota, ca $9^{\circ} 33^{\prime} \mathrm{N}, 83^{\circ}$ $48^{\prime} \mathrm{W}$, Weg von Ferienanlage Chacon zu 'Las Cruzes' am Rio Savegre, in Primärwald, epiphyll, $1900 \mathrm{~m}$ 
a.s.1., 25 December 1999, leg. A. Schäfer-Verwimp \& I. Holz $S V / H-0128 / D$ (INB, JE).

Guadeloupe: Basse Terre, Region La Soufriere, Trace Victor Hugues zwischen Matouba und Savane aux Ananas, ca $16^{\circ} 02^{\prime} \mathrm{N}, 61^{\circ} 39^{\prime} \mathrm{W}$, Regenwald, epiphyll, $1100 \mathrm{~m}$ a.s.1., 31 March 2002, leg. A. SchäferVerwimp \& I. Verwimp 22388/A (JE).

Radula mammosa was described from Bolivia and has subsequently been recorded from Colombia, Brazil and Chile (Castle, 1939; Yamada, 1993); more recent records are from southern Ecuador, in the provinces of Zamora-Chinchipe and Loja (Nöske et al., 2003; Schäfer-Verwimp et al., 2013); from Brazil (Yamada, 2003, state of Amazonas; Valente \& Pôrto, 2006; Berger \& Ribas, 2007; Tavares-Martins et al., 2014, states of Pará, Bahia, Rio de Janeiro and Santa Catarina) and from Venezuela (Morales \& Moreno, 2010). The collections from Costa Rica and Guadeloupe constitute a considerable extension of range to Central America and the West Indies. The altitudinal range of $R$. mammosa extends from $40 \mathrm{~m}$ a.s.l. in N Brazil (Tavares-Martins et al., 2014) up to $2900 \mathrm{~m}$ a.s.l. in southern Ecuador (Schäfer-Verwimp et al., 2013).

Gradstein et al. (2003) erroneously listed Radula lindigii Castle as a synonym of $R$. mammosa. The cited reference ('Castle, 1939') cited $R$. longituba Steph. and $R$. verrucifolia Steph. as synonyms, but $R$. lindigii was described 20 years later (Castle, 1959). The latter species has been accepted by Yamada (1986) and Uribe \& Gradstein (1998); however, it is not listed in the recent world checklist of liverworts and hornworts (Söderström et al., 2016).

\section{Riccardia chamedryfolia (With.) Grolle \\ Contributor: V. M. Virchenko}

Ukraine: the Crimea, Bilohirs'k district, outskirts of Karasivka village, the Karasu-Bashi spring, $44^{\circ} 58^{\prime} \mathrm{N}$, $34^{\circ} 36^{\prime} \mathrm{E}$; on small stones under the water; 28 May 2013, leg. Yu. I. Mala s.n., det. V. M. Virchenko (KW-B).

Riccardia chamedryfolia is known from most countries in Europe, as well as in Asia, North Africa and North America (Düll, 1983). In Russia the species has been reported from the European part of the country including the Ural Mountains, Caucasus, Siberia and the Far East (Potemkin \& Sofronova, 2009). The plant occurs on moist soil and wet rocks, on pond and lake margins, in fens and on dripping rocks and wet ledges in ravines (Dierßen, 2001). There are about ten localities of $R$. chamedryfolia in the Ukrainian Carpathians, where it grows on soil in wet places and near springs (Zerov \& Partyka, 1975). During a field study of bryophytes, the liverwort was also discovered in the SE Crimea, near Karasivka village of the Bilohirs'k district. This is the first record of the species in this peninsula. At present, including data in Partyka (2005), the bryophyte flora of the Crimea includes 40 species of liverworts.

Contributors: S. Poponessi, M. Aleffi, D. Gigante and R. Venanzoni

Italy: Boschi di Ferretto-Bagnolo Umbria Region, Province of Perugia. It is a Site of Community

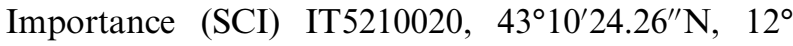
$00^{\prime} 02.13^{\prime \prime} \mathrm{E}$, ca $272 \mathrm{~m}$ a.s.1., on waterlogged soil with Isoetes histrix Bory \& Durieu, drying phase, 8 April 2015, leg. \& det. S. Poponessi s.n. (PERU).

The investigations during which this record was discovered focused on a system of Mediterranean temporary ponds categorised as a priority habitat under the EU Directive 92/43/EEC and listed in Annexe I with the code $3170^{*}$.

Riccardia chamedryfolia is considered Vulnerable (VU) in Italy according to Hodgetts (2015). It has been assigned to the Austrosubtropical/MountainArctic phytogeographical element (Dierßen, 2001). This constitutes the first record for Umbria. Its presence in the Italian peninsula has only recently been confirmed, in the Aosta Valley, Piedmont, Tuscany, Puglia, Calabria and Sardinia and Sicily (Aleffi et al., 2008). Its Mediterranean distribution range includes Bulgaria, the Canary Islands, Corsica, Crete, Spain, France, Greece, Madeira, Portugal and Turkey (Ros et al., 2007). In several countries it is considered at risk (Hodgetts, 2015).

\section{Riccia canaliculata Hoffm}

Contributors: S. Poponessi, M. Aleffi, D. Gigante and R. Venanzoni

Italy: Boschi di Ferretto-Bagnolo Umbria Region, Province of Perugia. It is a Site of Community

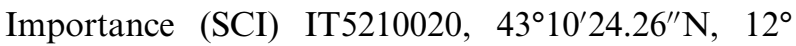
$00^{\prime} 02.13^{\prime \prime} \mathrm{E}$, ca $273 \mathrm{~m}$ a.s.1., on clay waterlogged soil in the shadow of Pinus pinea L.; $43^{\circ} 10.083^{\prime} \mathrm{N}, 11^{\circ}$ $58.267^{\prime} \mathrm{E}$, ca $272 \mathrm{~m}$ a.s.1., at the edge of a clay pond, 8 April 2015, leg. S. Poponessi, det. S. Poponessi s.n. (PERU);

The investigations during which this record was discovered focused on a system of Mediterranean temporary ponds categorised as a priority habitat under the EU Directive 92/43/EEC and listed in Annexe I with the code $3170 *$.

Riccia canaliculata is considered as Endangered (EN) in Italy both by Aleffi \& Schumacker (1995) and Hodgetts (2015). The present record is the first for Umbria. The species is very rarely found in Italy, and has only been confirmed in Lazio (Schwab, 1969, pers. comm.) and Sardinia (Bischler \& JovetAst, 1971-1972; Aleffi et al., 1995; Cogoni et al., 2004, 2006). According to Aleffi et al. (2008), the species is known in other regions of Italy (Piedmont, Lombardy, Veneto and Tuscany) from ancient reports. Its range includes Spain, Portugal, France, 
Greece, Corsica (Ros et al., 2007), North Africa, Macaronesia and South America, with a Mediterranean-Boreal phytogeographical element (Dierßen, 2001). It has been included in the Red Lists of several European countries (Hodgetts, 2015).

30. Seligeria acutifolia Lindb.

Contributors: Cs. Németh, A. Kovács and P. Erzberger

Hungary: Komárom-Esztergom County, Pilis Mts [8278.4] (Central European Mapping Scheme), ca $3 \mathrm{~km}$ south of the town of Esztergom, on the hill Nagy-Strázsa-hegy, on shaded limestone rock, ca $300 \mathrm{~m}$ a.s.1., $47^{\circ} 44^{\prime} 35.5^{\prime \prime} \mathrm{N}, 18^{\circ} 45^{\prime} 36.1^{\prime \prime} \mathrm{E}, 17$ March 2016, leg. Cs. Németh and A. Kovács (Hb. Németh 7895), det. P. Erzberger, 11 May 2016, conf. C. Schmidt, 23 May 2016.

Seligeria acutifolia is characterised by a short, straight seta, up to $1.5 \mathrm{~mm}$ long, and perichaetial leaves that are longer than the cauline leaves and often (nearly) reach the base of the capsule. The capsule is short, widest at the orifice when empty, and has a developed peristome. The spores are (9-) $12-14 \mu \mathrm{m}$, and the seta surface cells are short rectangular, not narrowly linear as in the closely related S. pusilla (Hedw.) Schimp. The leaf margin is very finely crenulated with slightly protruding cell ends. All these characters (except spore size) could be observed in the Hungarian plants, with many immature and some nearly mature capsules. This species usually grows on calcareous substrates, mostly under overhangs.

In Europe, S. acutifolia occurs mainly in western and southern countries; it appears to become rarer towards the east. The species occurs in only a few countries of eastern and south-eastern Europe, e.g. Austria, Croatia, Montenegro, Serbia and Greece, and is Red-Listed e.g. in the Czech Republic, Slovakia and Bulgaria (VU), whereas it is Data Deficient (DD) in Romania (Hodgetts, 2015). In Hungary it has possibly been overlooked for similar, but more common species of the genus. Seligeria acutifolia is missing from the latest checklist (Papp et al., 2010); it is new to the bryoflora of Hungary.

\section{Sphagnum molle Sull.}

Contributors: A. Stebel and R. Krawczyk

Poland, Podkarpackie Province: Sandomierz Basin: Nowa Dęba, vicinity of the 'Cietrzewiec' bog, $50^{\circ}$ $26^{\prime} 41^{\prime \prime} \mathrm{N}, 21^{\circ} 52^{\prime} 02^{\prime \prime} \mathrm{E}, 175 \mathrm{~m}$ a.s.1., 15 July 2012, leg. R. Krawczyk s.n. (SOSN).

Sphagnum molle is a very rare and threatened moss species in the bryoflora of Poland (Żarnowiec et al., 2004). In Europe it has a suboceanic geographical range (Dierßen, 2001), thus the overwhelming majority of its locations are situated in the western part of Poland, especially in Western Pomerania; single stations are known from the Orawsko-
Nowotarska Basin in the Western Carpathians (Melosik, 1992). A new location for $S$. molle has been found about $500 \mathrm{~km}$ south-east from its main centre of occurrence in Poland, near Nowa Dęba town. It occurs on sandy-peat soil in wet heath near a bog, associated with plants such as Calluna vulgaris (L.) Hull, Carex nigra Reichard, Drosera rotundifolia L., Eriophorum angustifolium Honck, E. vaginatum L., Juncus effusus L., J. squarrosus L., Molinia caerulea (L.) Moench, Pohlia nutans (Hedw.) Lindb., Polytrichum commune Hedw. and Sphagnum compactum Lam. \& DC. The vicinity of the 'Cietrzewiec' bog near Nowa Dęba is used as a military training area, thus the soil is disturbed. The population seems to be fairly plentiful and forms many small tufts. In a few of them sporophytes were observed. The present record is the easternmost location for this species in Poland and one of the south-easternmost in Europe (Daniels \& Eddy, 1990). Much further towards the south-east, this species is known in Lviv and Zhytomyr oblasts in Ukraine (Bojko, 2014).

32. Syntrichia subpapillosissima (Bizot \& R.B.Pierrot ex W.Kramer) M.T.Gallego \& J.Guerra

Contributors: S. Shirzadian and S. Akhoondi Darzikolaei

Iran: Khorasan Razavi province, Kalat, Zavin, $36^{\circ}$ $44^{\prime} \mathrm{N}, 59^{\circ} 54^{\prime} \mathrm{E}, 1260 \mathrm{~m}$ a.s.1., on rocks, 2 June 2015, leg. S. Shirzadian $0553 B$ (IRAN).

Akhani \& Kürschner (2004), in the latest checklist of the Iranian bryoflora, and Kürschner \& Frey (2011), in a bryophyte flora for Southwest Asia, list ten species of Syntrichia as occurring in Iran. Subsequently, Fereidounfar et al. (2011) recorded $S$. norvegica F.Weber from the Alvand Mountains in Hamedan province (Iran) and recently, Akhoondi et al. (2014) reported S. sinensis (Müll.Hal.) Ochyra from West Azarbaijan province (NW Iran). Consequently, 12 species of Syntrichia were recorded for Iran.

Syntrichia subpapillosissima, already known from Turkey (Kürschner \& Frey, 2011), usually occurs on calcareous, exposed or protected soils, sometimes on humiferous, sandy or stony soils; it can be saxicolous on granite, slate or sandstones, or rarely epiphytic (on Quercus spp. and Juniperus thurifera L.). It is usually found at altitudes between 400 and $4300 \mathrm{~m}$ a.s.1. The global distribution of S. subpapillosissima includes Europe, North Africa and south-western Asia (Gallego, 2005).

Plants of $S$. subpapillosissima reach $5 \mathrm{~cm}$ high, their laminal cells bear pedicellate and branched papillae (bifurcate, rarely stellately branched, 2.5-5.0 $\mu \mathrm{m}$ high and more than one per cell). This separates them from plants of the closely related $S$. papillosissima (Copp.) Loeske, which reach $8 \mathrm{~cm}$ high and have a lamina with only a single stellately branched papilla 
per cell on both sides of leaf, the papillae are 2.5$7.5 \mu \mathrm{m}$ high.

\section{Tritomaria koreana Bakalin, S.-S.Choi \&} B.Y.Sun

Contributor: V. A. Bakalin

Japan: Honshu, Yamanashi Pref., Japanese

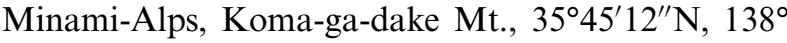
$13^{\prime} 46^{\prime \prime} \mathrm{E}, 2700 \mathrm{~m}$ a.s.1., Abies-Tsuga diversifolia forest on the ridge, mesic cliff crevices on steep N-facing slope, 30 September 2015, leg. V. A. Bakalin s.n. (VBGI: J-87-13-15).

Tritomaria koreana was recently described (Bakalin et al., 2009) from its only locality, in the southern part of the Korean Peninsula, and despite several searches was not found in the mountain systems of the Republic of Korea outside Jiri-san. The taxon was tentatively accepted as a separate species by Ván̆a et al. (2014). The present record in Japan is the first report of the taxon outside Korea. The habitat of $T$. koreana in the Southern Japanese Alps is quite similar to that in the Korean Peninsula. In the both places the species behaves as an acidophilic mesophyte, occupying thin soil in partially shaded cliff crevices in mountain oroboreal (subalpine in Japanese tradition) dark coniferous forests. In both localities the species produced gemmae, but was never found with sporophytes. Despite its copious production of gemmae, the species was observed in a very limited area and has not spread to the similar (at least visually) and fairly abundant cliff crevices in the surrounding mountains. I speculate that $T$. koreana may occur in some other mountain systems of Japan as well as in north-east China.

34. Vittia pachyloma (Mont.) Ochyra

Contributors: H. Bednarek-Ochyra and V. Plášek

Chile: XI Región Aysén del General Carlos Ibáñez del Campo, Provincia de General Carrera: Los Alamos south of Lago Negro at the southernmost end of Lago General Carrera, between Puerto Bertrand and Puerto Guadal at Carretera Austral-Ruta 7, 45 $54^{\prime} 360^{\prime \prime} \mathrm{S}, 72^{\circ} 19^{\prime} 213^{\prime \prime} \mathrm{W}, 346 \mathrm{~m}$ a.s.1., on submerged or exposed stones in a small stream flowing into Lago Bertrand, 16 January 2015, leg. H. Bednarek-Ochyra, R. Ochyra \& V. Plášek 564/ 15 (KRAM, SGO).

Vittia pachyloma has hitherto been recorded from three provinces of the XI Región Aysén in Chile, namely from Provincia de Aysén and Coyhaique (Müller, 2009) and Provincia de Capitán Prat (Ellis et al., 2016b). Here, the species is reported from the fourth province of this Región, the Provincia de General Carrera, and this means that it is known from all provinces in southern Chile which administratively belong to the XI and XII Regións. Vittia pachyloma is a common and abundant rheophytic moss in streams and rivers, usually with fast flowing water, growing firmly attached to rocks and blocks in river beds, often submerged or temporarily emergent. This is a challenging habitat for mosses, and in Chile $V$. pachyloma often grows together with Bucklandiella lamprocarpa (Müll.Hal.) Bednarek-Ochyra \& Ochyra and Scouleria patagonica (Mitt.) A.Jaeger. All of these species show adaptations for living in this type of habitat and exhibit remarkable convergence in their leaf structure. The most distinctive among these is the presence of fleshy multilayered marginal borders, which extend from the base to the apex of the leaves, where they are confluent with the salient costa (e.g. Touw \& Ochyra, 1987; Ochyra, 1987a; Ochyra \& Enroth, 1989; Ochyra \& Shevock, 2012). In addition, the laminal cells are usually bi- to polystratose (e.g. Ochyra, 1985a; Ochyra \& Vanderpoorten, 1999; Ochyra \& Bednarek-Ochyra, 2011) and the costa is strong and often occupies more than half the leaf width (e.g. Ochyra, 1985b, 1986a, 1986b, 2013; Ochyra et al., 1998; Shevock et al., 2011). Vittia pachyloma has long been considered as a member of the genus Sciaromium (Mitt.) Mitt. but this generic name proved to be synonymous with Echinodium Jur. (Ochyra, 1987b) and consequently a new generic name, Vittia Ochyra, was proposed as a replacement (Ochyra, 1987c).

Vittia pachyloma is a widely distributed species in South America, ranging along the Andes from Columbia to Tierra del Fuego and the Falkland Islands, appearing also in south-eastern Brazil and eastern Argentina (Ochyra, 1987c), and extending to subantarctic South Georgia (Ochyra \& Lightowlers, 1988). It then recurs at the highly disjunct amphiatlantic stations in Îles Kerguelen in the subantarctic South Indian Ocean. This type of distribution is shown by a number of moss species (e.g. Ochyra \& Lewis Smith, 1998; Bednarek-Ochyra \& Ochyra, 2010, 2012c, 2013; Ochyra, 2010; Ellis et al., 2012a, 2013a). The important centre of occurrence of $V$. pachyloma is in South Africa where it is known from some scattered localities in Mpumalanga (formerly Transvaal), KwaZulu-Natal (formerly Natal) and the Cape (Ochyra, 1987c). Accordingly, the species is classified as a classical Afro-American species, along with about other 80 species of moss (e.g. Frahm, 1982; Allen \& Crosby, 1986; Ochyra et al., 1992, 2002b; Wilbraham \& Matcham, 2010; Ellis et al., 2012b, 2014a, 2015b; Ochyra \& Ireland, 2016).

\section{Acknowledgements}

The work of V. A. Bakalin was partly supported by a grant from the Russian Foundation for Basic Researches (15-34-20101). Cs. Németh, A. Kovács and P. Erzberger thank C. Schmidt, Münster (Germany) for examining the specimen of Seligeria acutifolia. The contributions by H. Bednarek-Ochyra have been financially supported by the Polish 
National Centre of Science through grant No. N N 303796940 and, in part, through the statutory fund of the W. Szafer Institute of Botany of the Polish Academy of Sciences. She also thanks the Curators at AAS, LD, PC and S for the loan of the herbarium material. The field work of Marc Lebouvier on Îles Crozet was organised within the programme 136 ECOBIO of the French Polar Institute (IPEV). The contribution of V. Plášek was financially supported by EU structural funding Operational Programme Research and Development for Innovation, project No. CZ.1.05/2.1.00/19.0388 and the Ministry of Education, Youth and Sports of the Czech Republic in the 'National Feasibility Program I', project LO1208 'TEWEP'. The contribution by J. A. Calleja, R. Garilleti, V. Mazimpaka, B. Vigalondo and F. Lara was financially supported by the Spanish Ministries of Economy and Competitiveness (CGL2013-43246-P), and Science and Innovation (CGL2011-28857/BOS), and by the Ajuts a Grups de Recerca Consolidats-2014/SGR/ 00514. The work of M. J. Cano and L. Hedenäs was carried out with the financial support of the Spanish government (projects CGL2012-30721 and CGL2015-64068-P co-financed by FEDER). We are grateful to Montserrat Brugués for the loan of the samples of Orthothecium from BCB.

The contribution by B. Cykowska-Marzencka and M. Stryjak-Bogacka was financially supported by the statutory fund of the W. Szafer Institute of Botany of the Polish Academy of Sciences. The contribution by Michał Wegrzyn has been financially supported by the statutory fund of the Institute of Botany, Jagiellonian University.

The study by C. Sérgio and C. A. Garcia was financed by Portuguese National Funds, through FCT-Fundação para a Ciência e a Tecnologia, and the field work in Paul do Belo Jardim (Terceira Island, Azores) by J. Castillo Díaz was partially supported by the European program LIFE + (LIFE12 BIO/PT/000110). M. Kirmaci and E. Agcagil are very grateful to Adnan Menderes University (ADUBAP 12-006) for its financial support and to Dr Adnan Erdağ (Turkey) for confirming the identity of their Orthotrichum philibertii collection. J. Bruno Silva, Rangel Germano and N. Dias dos Santos thank SISBio, who granted them permission (under number 45504-1 in Ago 2014) to collect for scientific purposes in Vale do Catimbau National Park. V. M. Virchenko thanks Prof. RNDr. J. Váňa, D. Sc., Praha, Czech Republic, for checking the determination of his specimen of Riccardia chamedryfolia. The work of Y.-J. Yoon and J. H. Kim was supported by a grant from the Basic Research Program of Korea Polar Research Institute (PE16020). J. Enroth thanks Dr Halina Bednarek-Ochyra and Dr Ryszard
Ochyra for sending specimens from KRAM for examination.

Taxonomic Additions and Changes: Nil.

\section{ORCiD}

R. Garilleti (D) http://orcid.org/0000-0002-5977-2908

L. Hedenäs (D) http://orcid.org/0000-0003-1763-1696

J. Kučera (iD) http://orcid.org/0000-0002-0230-5997

\section{References}

Akhani, H. \& Kürschner, H. 2004. An annotated and updated checklist of the Iranian bryoflora. Cryptogamie, Bryologie, 25: $315-47$.

Akhoondi, S., Shirzadian, S. \& Eskandari, M. 2014. Syntrichia sinensis (Müll.Hal.) Ochyra (Pottiaceae), a new moss for Iranian bryoflora. Iranian Journal of Botany, 20: 109-11.

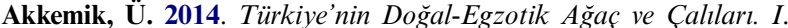
Ankara: Orman Genel Müdürlüğü Yayınları.

Aleffi, M. \& Carratello, A. 1998. La Sicilia, una "isola felice" per le briofite: specie nuove o rare per la flora briologica italiana. $93^{\circ}$ Congresso Società Botanica italiana, 1-3 Ottobre 1998: 70. Arcavacata di Rende.

Aleffi, M. \& Schumacker, R. 1995. Check-list and red-list of the liverworts (Marchantiophyta) and hornworts (Anthocerotophyta) of Italy. Flora Mediterranea, 5: 73-161.

Aleffi, M., Cogoni, A. \& Cortini Pedrotti, C. 1995. Contributo alla flora briologica del Massiccio del Gennargentu, territorio di Arzana (Sardegna centro-orientale). Informatore Botanico Italiano, 27(2-3): 201-18.

Aleffi, M., Tacchi, R. \& Cortini Pedrotti, C. 2008. Check-list of the hornworts, liverworts and mosses of Italy. Bocconea, 22: 1-255.

Allen, B.H. \& Crosby, M.R. 1986. Revision of the genus Squamidium (Musci: Meteoriaceae). Journal of the Hattori Botanical Laboratory, 61: 423-76.

Allen, B. \& Magill, R.E. 2003. A revision of Pilotrichella (Lembophyllaceae, Musci). Acta Academiae Paedagogicae Agriensis Sectio Biologicae, Nova Series, 24: 43-83.

Antonini, Y. \& Martins, R.P. 2003. The flowering-visiting bees at the ecological station of the Universidade Federal de Minas Gerais, Belo Horizonte, MG, Brazil. Neotropical Entomology, 32(4): 565-75.

Arnell, H.W. 1900. Beiträge zur Moosflora der Spitzbergischen Inselgruppe. Öfversigt af Förhandligar: Kongl. Svenska Vetenskaps -Akademien, 57: 99-130.

Arnell, H.W. \& Mårtensson, O. 1959. A contribution to the knowledge of the bryophyte flora of W. Spitsbergen, and Kongsfjorden (King's Bay, $79^{\circ}$ N.) in particular. Arkiv för Botanik, 4: 105-64.

Augier, J. 1966. Flore des bryophytes. Paris: Paul Lechevalier.

Bakalin, V.A., Choi, S.-S. \& Sun, B.-Y. 2009. A new species of Tritomaria (Lophoziaceae) from the Korean Peninsula. Arctoa, 18: 163-6.

Bednarek-Ochyra, H. \& Ochyra, R. 1998. Racomitrium lamprocarpum (Müll.Hal.) Jaeg. - an addition to the moss flora of Îles Kerguelen and the Subantarctic. Journal of Bryology, 20(2): 525-8.

Bednarek-Ochyra, H. \& Ochyra, R. 2003. Racomitrium patagonicum, a new moss species from southern South America. Journal of Bryology, 25(3): 181-7.

Bednarek-Ochyra, H. \& Ochyra, R. 2010. Bucklandiella allanfifei (Grimmiaceae), a new moss species from New Zealand, with a note on South American B. striatipila. Journal of Bryology, 32(4): $245-55$

Bednarek-Ochyra, H. \& Ochyra, R. 2011. Bucklandiella angustissima sp. nov. (Grimmiaceae), a new austral amphipacific species with the smallest capsules and the shortest setae in the genus. Cryptogamie, Bryologie, 32(1): 13-27.

Bednarek-Ochyra, H. \& Ochyra, R. 2012a. Antipodal mosses: XVII. Bucklandiella longtonii (Bryopsida, Grimmiaceae), a new species with caducous leaf apices from subantarctic South Georgia. Nova Hedwigia, 94: 373-84

Bednarek-Ochyra, H. \& Ochyra, R. 2012b. The taxonomic status of Racomitrium capense (Bryophyta, Grimmiaceae) from South Africa. Cryptogamie, Bryologie, 33(2): 97-106. 
Bednarek-Ochyra, H. \& Ochyra, R. 2012c. A consideration of Bucklandiella (Bryophyta, Grimmiaceae) in South America with a taxonomic re-assessment of Racomitrium looseri. Nova Hedwigia, 95: 153-63.

Bednarek-Ochyra, H. \& Ochyra, R. 2013. Diversity of Grimmiaceae subfam. Racomitrioideae in sub-Saharan Africa, including an addition of Bucklandiella striatipila to the moss flora of the continent. Cryptogamie, Bryologie, 34(1): 3-12.

Bednarek-Ochyra, H., Ochyra, R. \& Buck, W.R. 1999. The genus Racomitrium (Grimmiaceae) in Brazil, with the first report of R. subsecundum in South America. Brittonia, 51: 93-105.

Bednarek-Ochyra, H., Ochyra, R., Sawicki, J. \& Szczecińska, M. 2014. Bucklandiella seppeltii, a new species of Grimmiaceae from Australasia and its phylogenetic position based on molecular data. Turkish Journal of Botany, 38: 1214-28

Beever, J., Allison, K.W. \& Child, J. 1992. The mosses of New Zealand. 2nd ed. Dunedin: University of Otago Press.

Beike, A.K. \& Rensing, S.A. 2010. The Physcomitrella patens genome - a first stepping stone towards understanding bryophyte and land plant evolution. Bryophyte Diversity and Evolution, 31(1): 43-50.

Bell, B.G. 1974. A synoptic flora of South Georgian mosses: V. Willia and Racomitrium. British Antarctic Survey Bulletin, 38: 73-101.

Berger, J.Z. \& Ribas, O.S. 2007. Contribution to the hornwort and liverwort flora of Santa Catarina (Brazil). Boletim do Museu Botânico Municipal (Curitiba), 70: 1-11.

Berggren, S. 1875. Musci et Hepaticae Spetsbergenses. Bericht über die Untersuchung der Moosflora Spitzbergens und Beeren-Eilands während der Schwedichen Expeditionen 1864 und 1868, und Verzeichniss der dort gesemmelten arten. Kongliga Svenska Vetenskaps-Akademiens Handlingar, 13(7): $1-103$.

Birkenmajer, K., Ochyra, R., Olsson, I.U. \& Stuchlik, L. 1985. MidHolocene radiocarbon-dated peat at Admiralty Bay, King George Island (South Shetland Islands, West Antarctica). Bulletin of the Polish Academy of Sciences, Earth Sciences, 33: 7-13.

Bischler, H. \& Jovet-Ast, S. 1971-1972. Les Hepatiques de Sardaigne. Enumeration, notes ecologiques et biogeographiques. Revue Bryologique et Lichénologique, 38: 325-419.

Blockeel, T.L., Abay, G., Cetin, B., Bednarek-Ochyra, H., Ochyra, R., Lewis Smith, R.I., Matteri, C.M., Farias, R.M., Novotný, I., Rao, P., Enroth, J., van Rooy, J., Schiavone, M.M. \& Váňa, J. 2003. New national and regional bryophyte records, 7. Journal of Bryology, 25: 141-4.

Blockeel, T.L., Bednarek-Ochyra, H., Ochyra, R., Garcia, C., Matcham, H.W., Sérgio, C., Sim-Sim, M., Stebel, A. Townsend, C.C. \& Váňa, J. 2005. New national and regional bryophyte records, 11. Journal of Bryology, 27(2): 163-8.

Blockeel, T.L., Chlebicki, A., Hájková, P., Hájek, M., Hradílek, Z., Kürschner, H., Ochyra, R., Parolly, G., Plášek, V., Quandt, D., Townsend, C.C. \& Vanderpoorten, A. 2006a. New national and regional bryophyte records, 12. Journal of Bryology, 28(1): 68-70.

Blockeel, T.L., Bednarek-Ochyra, H., Ochyra, R., Hájková, P., Hájek, M., Kučera, J., Kürschner, H., Müller, F., Olivá, G., Parolly, G., Porley, R.D., Rams, S., Séneca, A., Sérgio, C. Townsend, C.C., Tyshchenko, O. \& Vieira, C. 2006b. New national and regional bryophyte records, 13. Journal of Bryology, 28(2): 151-5.

Blockeel, T.L., Enroth, J., Ertz, D., Hedderson, T.A.J., Holz, I. Jafari, M., Kürschner, H., Lara, F., Mazimpaka, V., Medina, R., Ramel, G., Schäfer-Verwimp, A., Shirzadian, S., Sotiaux A., Sotiaux, O., Stebel, A. \& Tavili, A. 2006c. New national and regional bryophyte records, 14. Journal of Bryology, 28 (3): $271-5$.

Blockeel, T.L., Bednarek-Ochyra, H., Ochyra, R., Garilleti, R., Glime, J.M., Lara, F., Mazimpaka, V., Rusińska, A., SchäferVerwimp, A., Shabbara, H.M., Söderström, L., Stebel, A. Townsend, C.C., Váňa, J., Yayintaș, Ö.T. \& Zarnowiec, J. 2007. New national and regional bryophyte records, 17 Journal of Bryology, 29(4): 277-83.

Blockeel, T.L., Bakalin, V.A., Bednarek-Ochyra, H., Ochyra, R., Buck, W.R., Choi, S., Cykowska, B., Erdağ, A., Erzberger, P. Kirmaci, M., Kürschner, H., Lebouvier, M., Papp, B. Sabovljević, M., Sabovljević, A., Schröder, W., Singh, S.M., Sun, B.-Y., Townsend, C.C., Váňa, J. \& Yayintaș, Ö.T. 2009. New national and regional bryophyte records, 20. Journal of Bryology, 31(1): 54-62.
Blockeel, T.L., Bednarek-Ochyra, H., Cykowska, B., Ochyra, R., Düzenli, A., Ezer, T., Holyoak, D.T., Hugonnot, V., Kara, R., Larrain, J., Lebouvier, M., Preston, C.D., Schäfer-Verwimp, A., Smith, V.R., Spitale, D., Ştefănuț, S. \& Váňa, J. 2010. New national and regional bryophyte records, 23. Journal of Bryology, 32(2): 140-7.

Boińska, U. \& Gugnacka-Fiedor, W. 1986. Bryophytes and their distribution in the tundra communities of the Kaffiöyra Plain (NW Spitsbergen). Fragmenta Floristica et Geobotanica, 29: 401-13.

Bojko, M.F. 2014. The second checklist of bryobionta of Ukraine. Czornomorskyj Botanicznyj Żurnat, 10(4): 426-87.

Bordin, J. \& Yano, O. 2009. Novas ocorrências de musgos (Bryophyta) para o Estado do Rio Grande do Sul, Brasil. Revista Brasileira de Botânica, 32: 455-77.

Boudier, P. \& Pierrot, R.B. 1992. Contribution à la bryoflore des Hautes-Alpes et des Alpes-de-Haute-Provence. Bulletin de la Société Botanique du Centre-Ouest N.S., 23: 319-34.

Brotherus, V.F. 1906. Die Laubmoose der Deutschen SüdpolarExpedition 1901-1903. In: E. von Drygalski, ed. Deutsche Südpolar-Expedition 1901-1903 im Auftrage des Reichsamtes des Innern. 8 (Botanik). Berlin: Georg Reimer, pp. 83-96.

Brown, R. 1893. Notes on the New Zealand species of the genus Andreaea, together with description of some new species. Transactions and Proceedings of the New Zealand Institute, 25: $276-87$ + pls. xxi-Xxxi.

Buchbender, V., Hespanhol, H., Krug, M., Sérgio, C., Séneca, A., Maul, K., Hedenäs, L. \& Quandt, D. 2014. Phylogenetic reconstructions of the Hedwigiaceae reveal cryptic speciation and hybridisation in Hedwigia. Bryophyte Diversity and Evolution, 36(1): 1-21.

Buck, W.R. 2003. Guide to the plants of central French Guiana. Part 3. Mosses. Memoirs of the New York Botanical Garden, 76(3): $1-167$

Bussmann, R.W. 2006. Vegetation zonation and nomenclature of African mountains - an overview. Lyonia, 11(1): 41-66.

Bytebier, B. \& Chuah-Petiot, M. 2002. A preliminary checklist of the bryoflora of the Taita Hills, Kenya. Tropical Bryology, 22: $55-66$.

Cardot, J. \& Brotherus, V.F. 1923. Botanische Ergebnisse der Schwedischen Expedition nach Patagonien und dem Feuerlande 1907-1909. X. Les mousses. Kongliga Svenska Vetenskapsakademiens Handlingar, 63(10): 1-74 + pls. 1-4.

Carratello, A. 2004. Flora briologica e considerazioni briogeografiche delle Isole dello Stagnone (Sicilia occidentale). BraunBlanquetia, 34: 189-205.

Castle, H. 1939. A revision of the genus Radula. Part II. Subgenus Acroradula. Section 1. Epiphyllae. Annales Bryologici, 12: 21-47.

Castle, H. 1959. A revision of the genus Radula. Part II. Subgenus Acroradula section 3. Dichotomae. Journal of the Hattori Botanical Laboratory, 21: 1-52.

Chikovani, N. \& Svanidze, T. 2004. Checklist of bryophyte species of Georgia. Braun-Blanquetia, 34: 97-116.

Chrapusta, E., Wegrzyn, M., Zabaglo, K., Kaminski, A., Adamski, M., Wietrzyk, P. \& Bialczyk, J. 2015. Microcystins and anatoxin-a in Arctic biocrust cyanobacterial communities. Toxicon, 101: 35-40

Churchill, S.P. \& Linares, E.L. 1995 Prodomus Bryologiae Novo Granatensis. Introducción a la flora de musgos de Colombia. Biblioteca José Jerónimo Triana. Tomos I y II. Bogotá: Instituto de Ciencias Naturales. Facultad de Ciencias. Universidad Nacional de Colombia.

Churchill, S.P., Sanjines, A.N.N. \& Aldana, M.C. 2009. Catálogo de las Briofitas de Bolivia: Diversidad, Distributión y Ecología. St. Luiz: Missouri Botanical Garden \& Santa Cruz: Museo Noel Kempff Mercado.

Clarke, G.C.S. 1973. A synoptic flora of South Georgian mosses: III. Leptotheca, Philonotis, Mielichhoferia and Pohlia. British Antarctic Survey Bulletin, 37: 53-79.

Cogoni, A., Flore, F., Adamo, C. \& Scrugli, A. 2004. Bryological flora of the Giara di Gesturi Tableland (southern-central Sardinia). Braun-Blanquetia, 34: 51-8.

Cogoni, A., Adamo, C. \& Flore, F. 2006. Su alcuni nuovi o interessanti reperti della brioflora sarda. Informatore Botanica Italiano, 38: 145-8.

Cortini Pedrotti, C. 2001. Flora dei Muschi d'Italia. Sphagnopsida, Andreaeopsida, Bryopsida (I parte). Rome: Antonio Delfino Editore.

Crundwell, A.C. \& Nyholm, E. 1964. The European species of the Bryum erythrocarpum complex. Transactions of the British Bryological Society, 4: 596-637. 
Cykowska, B. 2014. Phaeomegaceros fimbriatus (Gottsche) Duff, J.C.Villarreal, Cargill et Renzaglia new to Bolivia Cryptogamie, Bryologie, 35(1): 99-103.

Cykowska-Marzencka, B. 2013. Taxonomy, diversity and distribution of bryophytes in Polish Carpathians: Cephaloziella spinigera (Lindb.) Warnst. Acta Biologica Cracoviensa series Botanica, 55 (supplement 1): 41.

Damsholt, K. 2002. Illustrated flora of Nordic liverworts and hornworts. Lund: Nordic Bryological Society, Lund University.

Daniels, R.E. \& Eddy, A. 1990. Handbook of European Sphagna. London: HMSO.

Deguchi, H. 1984. Studies on some Patagonian species of Grimmiaceae (Musci, Bryophyta). In: H. Inoue, ed. Studies on cryptogams in southern Chile. Tokyo: Kenseisha, pp. 17-72.

Dierßen, K. 2001. Distribution, ecological amplitude and phytosociological characterization of European bryophytes. Bryophytorum Bibliotheca, 56: 1-289.

Dixon, H.N. 1918. The mosses collected by the Smithsonian African Expedition 1909-10. Smithsonian Miscellaneous Collections, 69 (2): $1-28+2$ plates

Düll, R. 1983. Distribution of the European and Macaronesian liverworts (Hepaticophytina). Bryologische Beitraege, 2: 1-115.

Düll, R. 1985. Distribution of the European and Macaronesian mosses (Bryophytina). Part II. Bryologische Beiträge, 5: $110-232$.

Ellis, L.T., Dickson, J.H., Eckstein, J., Fontinha, S., Hedenas, L., Horton, D., Hugonnot, V., Kirmaci, M., Kučera, J., Lobo, C. Luis, L., Sim-Sim, M., Singh, H., Sahu, V., Husain, T. Asthana, A.K., Stech, M., Kruijer, J.D., Sotiaux, A., Suárez, G.M., Schiavone, M.M. \& Vanderpoorten, A. 2010. New national and regional bryophyte records, 24. Journal of Bryology, 32(3): 232-41.

Ellis, L.T., Akhoondi Darzikolaei, S., Shirzadian, S., Bakalin, V.A., Bednarek-Ochyra, H., Ochyra, R., Claro, D., Dulin, M.V., Eckel, P.M., Erzberger, P., Eziz, R., Sulayman, M., Garcia, C., Sérgio, C., Stow, S., Hedderson, T., Hedenäs, L., Kürschner, H., Li, W., Nebel, M., Nieuwkoop, J., Philippov, D.A., Plášek, V., Sawicki, J., Schäfer-Verwimp, A., Stefănut, S. \& Váňa, J. 2011. New national and regional bryophyte records, 29. Journal of Bryology, 33(4): 316-23.

Ellis, L.T., Alegro, A., Bednarek-Ochyra, H., Ochyra, R., Bergamini, A., Cogoni, A., Erzberger, P., Górski, P., Gremmen, N. Hespanhol, H., Vieira, C., Kurbatova, L.E., Lebouvier, M. Martinčič, A., Asthana, A.K., Gupta, R., Nath, V., Natcheva, R., Ganeva, A., Özdemir, T., Batan, N., Plášek, V., Porley, R.D., Randić, M., Sawicki, J., Schroder, W., Sérgio, C. Smith, V.R., Sollman, P., Ştefănuț, S., Stevenson, C.R., Suárez, G.M., Surina, B., Uyar, G. \& Modrič Surina, Z 2012a. New national and regional bryophyte records, 31 . Journal of Bryology, 34(2): 123-34

Ellis, L.T., Alegro, A., Bansal, P., Nath, V., Cykowska, B., BednarekOchyra, H., Ochyra, R., Dulin, M.V., Erzberger, P., Garcia, C. Sérgio, C., Claro, D., Stow, S., Hedderson, T.A., Hodgetts, N.G., Hugonnot, V., Kucěra, J., Lara, F., Pertierra, L., Lebouvier, M., Liepina, L., Mežaka, A., Strazdiṇa, L. Madžule, L., Rēriha, I., Mazooji, A., Natcheva, R., Phephu, N., Philippov, D.A., Plášek, V., Cihal, L., Pócs, T., Porley, R.D., Sabovljević, M., Salimpour, F., Berhroozmand Motlagh, M., Sharifnia, F., Akhoondi Darzikolaei, S., Schäfer-Verwimp, A., Segota, V., Shaw, A.J., Sim-Sim, M., Sollman, P., Spitale, D., Hölzer, A., Stebel, A., Váňa, J., van Rooy, J. \& Vončina G. 2012b. New national and regional bryophyte records, 32 Journal of Bryology, 34(3): 231-46.

Ellis, L.T., Bednarek-Ochyra, H., Ochyra, R., Cykowska, B., Dulin, M.V., Ezer, T., Kara, R., Flores, J.R., Suárez, G.M., Garcia, C. Martins, A., Sérgio, C., Garilleti, R., Kırmacı, M., Agcagil, E. Kurbatova, L.E., Lebouvier, M., Papp, B., Szurdoki, E. Philippov, D.A., Plášek, V., Pócs, T., Sabovljević, M., Sawicki, J., Sim-Sim, M., Szücs, P., Bidló, A., Váňa, J., Vigalondo, B. Lara, F., Draper, I., Virchenko, V.M. \& Wolski, G.J. 2012c. New national and regional bryophyte records, 33. Journal of Bryology, 34(4): 281-91

Ellis, L.T., Asthana, A.K., Gupta, R., Nath, V., Sahu, V., BednarekOchyra, H., Ochyra, R., Cykowska, B., Calvo Aranda, S. Fischer, E., Gabriel, R., Górski, P., Gremmen, N., Hespanhol, H., Kurbatova, L.E., Lewis Smith, R.I., Long, D.G., Bell, D. Mogro, F., Sérgio, C., Garcia, C.A., Stow, S., Martins, A. Smith, V.R., Váňa, J. \& Vanderpoorten, A. 2013a. New national and regional bryophyte records, 34. Journal of Bryology, 35(1): $62-70$.
Ellis, L.T., Bednarek-Ochyra, H., Ochyra, R., Benjumea, M.J., Saïs, L.V., Caparrós, R., Lara, F., Mazimpaka, V., Dulin, M.V., Garilleti, R., Gremmen, N., Grundling, P.-L., Heras, P., Infante, M., Huttunen, S., Ignatov, M.S., Korvenpää, T., Lebouvier, M., Lewis Smith, R.I., Lin, S.-H., Yang, J.-D., Linström, A., Plášek, V., Rosselló, J.A., Sawicki, J., van Rooy, J. \& Smith, V.R. 2013b. New national and regional bryophyte records, 35. Journal of Bryology, 35(2): 129-39.

Ellis, L.T., Bakalin, V.A., Baisheva, E., Bednarek-Ochyra, H., Ochyra, R., Borovichev, E.A., Choi, S.S., Sun, B.-Y., Erzberger, P., Fedosov, V.E., Garilleti, R., Albertos, B., Górski, P., Hájková, P., Hodgetts, N.G., Ignatov, M., Koczur, A., Kurbatova, L.E., Lebouvier, M., Mežaka, A., Miravet, J., Pawlikowski, P., Porley, R.D., Rosselló, J.A., Sabovljević, M.S., Pantović, J., Sabovljević, A., Schröder, W., Ştefănuţ, S., Suárez, G.M., Schiavone, M., Yayintaş, Ö.T. \& Váňa, J. 2013c. New national and regional bryophyte records, 36. Journal of Bryology, 35(3): 228-38.

Ellis, L.T., Aranda, S.C., Asthana, A.K., Bansal, P., Nath, V., Sahu, V., Bayliss, J., Asthana, G., Srivastava, S., Yadav, S., Brugués, M., Cano, M.J., Dulin, M.V., Fudali, E., Fuertes, E., Gabriel, R., Pereira, F., Silva, J.A.F., Gradstein, S.R., Hájková, P., Hájek, M., Heras, P., Infante, M., Lebouvier, M., Marka, J., Newsham, K.K., Ochyra, R., Pantović, J., Sabovljević, M.S., Phephu, N., van Rooy, J., Philippov, D.A., Porley, R.D., Puche, F., Schäfer-Verwimp, A., Segarra-Moragues, J.G., Sérgio, C., Smith, V.R., Stefănut, S., Váňa, J. \& Wigginton, M.J. 2013d. New national and regional bryophyte records, 37. Journal of Bryology, 35(4): 290-305.

Ellis, L.T., Bayliss, J., Bruggeman-Nannenga, M.A., Cykowska, B., Ochyra, R., Gremmen, N.J.M., Frahm, J.-P., Hedderson, T.A., Heras, P., Infante, M.V., Hugonnot, V., Mogro, F., Plášek, V., Cíhal, L., Sawicki, J., Schäfer-Verwimp, A., Stebel, A., Ştefănuț, S., Váňa, J., Yang, J.-D. \& Lin, S.-H. 2014a. New national and regional bryophyte records, 38. Journal of Bryology, 36(1): 61-72.

Ellis, L.T., Afonina, O.M., Asthana, A.K., Gupta, R., Sahu, V., Nath, V., Batan, N., Bednarek-Ochyra, H., Benitez, A., Erzberger, P., Fedosov, V.E., Górski, P., Gradstein, S.R., Gremmen, N., Hallingbäck, T., Hagström, M., Köckinger, H., Lebouvier, M., Meinunger, L., Németh, C., Nobis, M., Nowak, A., Özdemir, T., Pantović, J., Sabovljević, A., Sabovljević, M.S., Pawlikowski, P., Plášek, V., Cíhal, L., Sawicki, J., Sérgio, C., Ministro, P., Garcia, C.A., Smith, V.R., Stefănuț, S., Stow, S., Suárez, G.M., Flores, J.R., Thouvenot, L., Váňa, J., van Rooy, J. \& Zander, R.H. 2014b. New national and regional bryophyte records, 39. Journal of Bryology, 36(2): 134-51.

Ellis, L.T., Aleffi, M., Tacchi, R., Alegro, A., Alonso, M., Asthana, A.K., Sahu, V., Biasuso, A.B., Callaghan, D.A., Ezer, T., Kara, R., Seyli, T., Garilleti, R., Gil-López, M.J., GwynneEvans, D., Hedderson, T.A., Kiebacher, T., Larrain, J., Long, D., Lüth, M., Malcolm, B., Mamontov, Y.S., Newsham, K.K., Nobis, M., Nowak, A., Ochyra, R., Pawlikowski, P., Plášek, V., Čihal, L., Potemkin, A.D., Puche, F., Rios, D., Gallego, M.T., Guerra, J., Sawicki, J., Schäfer-Verwimp, A., SegarraMoragues, J.G., Šegota, V., Sofronova, E.V., Ştefănuț, S., Szűcs, P., Bidló, A., Papp, B., Szurdoki, E., Tan, B.C., Váňa, J., Vigalondo, B., Draper, I., Lara, F., Yoon, Y.-J., Sun, B.-Y. \& Nishimura, N. 2014c. New national and regional bryophyte records, 41. Journal of Bryology, 36(4): 306-24.

Ellis, L.T., Asthana, A.K., Srivastava, A., Bakalin, V.A., BednarekOchyra, H., Cano, M.J., Jiménez, J.A., Alonso, M., Deme, J., Csiky, J., Dia, M.G., Campisi, P., Erzberger, P., Garilleti, R., Gorobets, K.V., Gremmen, N.J.M., Jimenez, M.S., Suárez, G.M., Jukonienė, I., Kiebacher, T., Kırmacı, M., Koczur, A., Kürschner, H., Lara, F., Mazimpaka, V., Larraín, J., Lebouvier, M., Medina, R., Natcheva, R., Newsham, K.K., Nobis, M., Nowak, A., Ören, M., Ozcçelik, A.D., Orgaz, J.D., Peralta, D.F., Plášek, V., Cíhal, L., Ristow, R., Sawicki, J., Schäfer-Verwimp, A., Smith, V.R., Stebel, A., Stefănut, S., Subkaitė, M., Sun, B.-Y., Uselienė, A., Uyar, G., Váňa, J., Yoon, Y.-J. \& Park, S.J. 2015a. New national and regional bryophyte records, 43. Journal of Bryology, 37 (2): $128-46$.

Ellis, L.T., Alegro, A., Šegota, V., Bakalin, V.A., Barone, R., Borovichev, E.A., Hugonnot, V., Lebouvier, M., Nobis, M., Nowak, A., Ochyra, R., Papp, B., Szurdoki, E., Piwowarczyk, R., Plášek, V., Cíhal, L., Ren, Z.-J., Sabovljević, M.S., Sérgio, C., Garcia, C.A., Melo, I., Sawicki, J., Stebel, A., Stefănut, S., Ion, R., Manole, A., Tziortzis, I., Xiong, Y. \& Zhao, Z.-T. 
2015b. New national and regional bryophyte records, 44 Journal of Bryology, 37(3): 228-41.

Ellis, L.T., Ah-Peng, C., Aranda, S.C., Bednarek-Ochyra, H., Borovichev, E.A., Cykowska-Marzencka, B., Duarte, M.C., Enroth, J., Erzberger, P., Fedosov, V., Fojcik, B., Gabriel, R., Coelho, M.C.M., Henriques, D.S.G., Ilina, O.V., Gil-Novoa, J.E., Morales-Puentes, M.E., Gradstein, S.R., Gupta, R., Nath, V., Asthana, A.K., Koczur, A., Lebouvier, M. Mesterházy, A., Mogro, F., Mežaka, A., Németh, Cs., Orgaz, J.D., Sakamoto, Y., Paiva, J., Sales, F., Pande, N., Sabovljević, M.S., Pantivić, J., Sabovljević, A.D., PérezHaase, A., Pinheiro da Costa, D., Plášek, V., Sawicki, J., Szczecińska, M., Chmielewski, J., Potemkin, A., SchäferVerwimp, A., Schofield, W.B., Sérgio, C., Sim-Sim, M., Sjögren, S., Spitale, D., Stebel, A., Ştefănuț, S., Suárez, G.M., Flores, J.R., Thouvenot, L., Váňa, J., Yoon, Y.-J., Kim, J.H. \& Zubel, R. 2015c. New national and regional bryophyte records, 45. Journal of Bryology, 37(4): 308-29.

Ellis, L.T., Asthana, A.K., Srivastava, P., Omar, I., Rawat, K.K., Sahu, V., Cano, M.J., Costa, D.P., Dias, E.M., Dias dos Santos, N., Silva, J.B., Fedosov, V.E., Kozhin, M.N., Ignatova, E.A., Germano, S.R., Golovina, E.O., Gremmen, N.J.M., Ion, R., Ştefănuţ, S., Larraín, J., von Konrat, M., Jimenez, M.S., Suárez, G.M., Kiebacher, T., Lebouvier, M., Long, D.G., Maity, D., Ochyra, R., Parnikoza, I., Plášek, V., Fialová, L. Skoupá, Z., Poponessi, S., Aleffi, M., Sabovljević, M.S., Sabovljević, A.D., Saha, P., Aziz, M.N., Sawicki, J., Suleiman, M., Sun, B.-Y., Váňa, J., Wójcik, T., Yoon, Y.-J., Żarnowiec, J. \& Larraín, J. 2016a. New national and regional bryophyte records, 46. Journal of Bryology, 38(1): 47-63.

Ellis, L.T., Alataş, M., Asthana, A.K., Rawat, K.K., Sahu, V., Srivastava, A., Bakalin, V.A., Batan, N., Bednarek-Ochyra, H., Bester, S.P., Borovichev, E.A., De Beer, D., Enroth, J., Erzberger, P., Fedosov, V.E., Feuillet-Hurtado, C., Gradstein, S.R., Gremmen, N.J.M., Hedenäs, L., Katagiri, T., Yamaguchi, T., Lebouvier, M., Maity, D., Mesterházy, A., Müller, F., Natcheva, R., Németh, Cs., Opisso, J., Özdemir, T., Erata, H., Parnikoza, I., Plášek, V., Sabovljević, S. Sabovljević, A.D., Saha, P., Nehal Aziz, Md., Schröder, W. Váňa, J., van Rooy, J., Wang, J., Yoon, Y.-J. \& Kim, J.H. 2016b. New national and regional bryophyte records, 47. Journal of Bryology, 38(2): 151-67.

Ellis, L.T., Aleffi, M., Alegro, A., Segota, V., Asthana, A.K., Gupta, R., Singh, V.J., Bakalin, V.A., Bednarek-Ochyra, H., Cykowska-Marzencka, B., Benitez, A., Borovichev, E.A., Vilnet, A.A., Konstantinova, N.A., Buck, W.R., Cacciatoro, C., Sérgio, C., Csiky, J., Deme, J., Kovács, D., Damsholt, K., Enroth, J., Erzberger, P., Fedosov, V.E., Fuertes, E., Gradstein, S.R., Gremmen, N.J.M., Hallingbäck, T., Jukonienė, I., Kiebacher, T., Larraín, J., Lebouvier, M., Lüth, M. Mamontov, Yu.S., Potemkin, A.D., Nemeth, Cs., Nieuwkoop, J.A.W., Nobis, M., Osorio, F., Parnikoza, I., Perlata, D.F., Carmo, D.M., Plášek, V., Skoupá, Z., Poponessi, S., Venanzoni, R., Puche, F., Purger, D., Reeb, C., Rios, R., Rodriguez-Quiel, E., Arrocha, C., Sabovljević, M.S., Nikolić, N., Sabovljević, A.D., dos Santos, E.L., Segarra-Moragues, J.G., Stefănut, S., Stončius, D., Virchenko, V.M., Wegrzyn, M. \& Wietrzyk, P. 2016c. New national and regional bryophyte records, 48. Journal of Bryology, 38(3): 235-59.

Enroth, J. 1993. Notes on the Neckeraceae (Musci). 17. A taxonomic study on the genus Neckeropsis in Africa. Journal of the Hattori Botanical Laboratory, 73: 159-73.

Erzberger, P. \& Schröder, W. 2013. The genus Bryum (Bryaceae, Musci) in Hungary. Studia Botanica Hungarica, 44: 5-192.

Fereidounfar, S., Shirzadian, S., Ranjbar, M. \& Ghahremaninejad, F. 2011. A survey to the moss flora of Alvand Mountains in Hamedan province, W Iran. Iranian Journal of Botany, 17: 125-32.

Frahm, J.-P. 1982. Grossdisjunktionen von Arealen Südamerikanischer und Afrikanischer Campylopus-Arten. Lindbergia, 8: 45-52.

Frisvoll, A.A. \& Elvebakk, A. 1996. Part 2. Bryophytes. In: A. Elvebakk \& P. Prestrud, eds. A catalogue of Svalbard plants, fungi, algae and cyanobacteria. Norsk Polarinstitut Skrifter, 198: 57-172.

Furuki, T. \& Mizutani, M. 1994. Checklist of Japanese Hepaticae and Anthocerotae, 1993. Proceedings of the Bryological Society of Japan, 6: 75-83.

Gallego, M.T. 2005. A taxonomic study of the genus Syntrichia Brid (Pottiaceae, Musci) in the Mediterranean region and
Macaronesia. Journal of Hattori Botanical Laboratory, 98: 47-122.

Gallego, M.T., Cano, M.J. \& Guerra, J. 2014. New chorological data on Hedwigia striata (Bruch \& Schimp.) Bosw., (Hedwigiaceae, Musci) in Spain, and remarks on its morphological characters. Anales de Biología, 36: 5-9.

Glime, J.M. 2015. Ecophysiology of development: hormones. Chapt. 5-1. In: J. M. Glime, ed. Bryophyte ecology. Volume 1. 5-1. Physiological ecology. Ebook sponsored by Michigan Technological University and the International Association of Bryologists, Available at <www.bryoecol.mtu.edu $>$. http ://www.bryoecol.mtu.edu/chapters/5-1Hormones.pdf.

Gradstein, S.R., Meneses, Q.R.I. \& Arbe, B.A. 2003. Catalogue of the Hepaticae and Anthocerotae of Bolivia. Journal of the Hattori Botanical Laboratory, 93: 1-67.

Graham, A.G.C., Fretwell, P.T., Larter, R.D., Hodgson, D.A., Wilson, C.K., Tate, A.J. \& Morris, P. 2008. A new bathymetric compilation highlighting extensive paleo-ice sheet drainage on the continental shelf, South Georgia, sub-Antarctica. Geochemistry Geophysics Geosystems, 9: 1-21.

Grolle, R. 1960. Beitrag zur Kenntnis von Barbilophozia, insbesondere B. florkei und B. hatcheri. Nova Hedwigia, 2: 555-66.

Grolle, R. 2002. The Hepaticae and Anthocerotae of the subantarctic and temperate islands in the eastern southern hemisphere $\left(90^{\circ} \mathrm{E}\right.$ to $\left.0^{\circ}\right)$ : an annotated catalogue. Journal of Bryology, 24: $57-80$

Guerra, J. 1985. Orthotrichum bistratosum (Schiffn.) Guerra, comb. et stat. nov. Anales Jardín Botánico de Madrid, 42(1): 284.

Guerra, J., Brugués, M., Cano, M.J. \& Cros, R.M. (eds.) 2010. Flora Briofitica Ibérica. Funariales, Splachnales, Schistostegales, Bryales, Timmiales. Vol. IV, Murcia: Universidad de Murcia, Sociedad Española de Briología, pp. 317.

Hagen, I. 1908. The mosses and hepatics of Prince Charles Foreland, Spitsbergen. Transactions of the Botanical Society of Edinburgh, 23: $326-30$.

Hallingbäck, T., Hedenäs, L. \& Weibull, H. 2006. Ny checklista för Sveriges mossor [Checklist of bryophytes recorded from Sweden]. Svensk Botanisk Tidskrift, 100(2): 96-148.

Hässel de Menéndez, G. \& Rubies, F.M. 2009. Catalogue of Marchantiophyta and Anthocerotophyta of southern South America [Chile, Argentina and Uruguay, including Easter Is. (Pascua I.), Malvinas Is. (Falkland Is.), South Georgia Is., and the subantarctic South Shetland Is., South Sandwich Is., and South Orkney Is.]. Nova Hedwigia Beiheft, 134: 1-672.

Hespanhol, H., Sérgio, C., Garcia, C. \& Viera, C. 2013. New distribution data on Hedwigia striata (Wilson) Bosw., a forgotten and misplaced taxon, in Portugal. Boletin de la Sociedad Española de Briologia, 40-41: 49-53.

Hill, M.O., Preston, C.D. \& Smith, A.J.E. 1994. Atlas of the bryophytes of Britain and Ireland. Vol. 3. Mosses (Diplolepideae). Colchester: Harley Books.

Hill, M.O., Bell, N., Bruggeman-Nannenga, M.A., Brugués, M. Cano, M.J., Enroth, J., Flatberg, K.I., Frahm, J.-P., Gallego, M.T., Garilleti, R., Guerra, J., Hedenäs, L., Holyoak, D.T., Hyvönen, J., Ignatov, M.S., Lara, F., Mazimpaka, V., Muñoz, J. \& Söderström, L. 2006. An annotated checklist of the mosses of Europe and Macaronesia. Journal of Bryology, 28: $198-267$

Hodgetts, N.G. 2015. Checklist and country status of European bryophytes-towards a new Red List for Europe. Irish Wildlife Manuals, 84. Dublin: National Parks and Wildlife Service, Department of Arts, Heritage and the Gaeltacht.

Hofmann, H. 2014. Bryum gemmiferum R.Wilczek \& Demaret. Moosflora der Schweiz. [accessed 10 March 2016]. Available at: <http://www.swissbryophytes.ch/content/artportrait? taxon id $=2692>$

Husnot, T. 1884-1890. Muscologia Gallica. Paris: F. Savy.

Ignatov, M.S., Ando, H. \& Ignatova, E.A. 1996. Bryophyte flora of Altai Mountains. VII. Hypnaceae and related pleurocarps with bi- or ecostate leaves. Arctoa, 6: 21-112.

Ignatov, M.S., Afonina, O.M., Ignatova, E.A., Abolina, A.A., Akatova, T.V., Baisheva, E.Z., Bardunov, L.V., Baryakina, E.A., Belkina, O.A., Bezgodov, A.G., Boychuk, M.A., Cherdantseva, V.Ya., Czernyadjeva, I.V., Doroshina, G.Ya., Dyachenko, A.P., Fedosov, V.E., Goldberg, I.L., Ivanova, E.I., Jukoniene, I.I., Kannukene, L.I., Kazanovsky, S.G., Kharzinov, Z.Kh., Kurbatova, L.E., Maksimov, A.I., Mamatkulov, U.K., Manakyan, V.A., Maslovsky, O.M., Napreenko, M.G., Otnyukova, T.N., Partyka, L.Ya., Pisarenko, O.Yu., Popova, N.N., Rykovsky, G.F., Tubanova, D.Ya., Zheleznova, G.V. \& 
Zolotov, V.I. 2006. Checklist of mosses of East Europe and North Asia. Arctoa, 15: 1-130.

Ireland, R.R. 1992. The moss genus Isopterygium (Hypnaceae) in Latin America. Tropical Bryology, 6(1): 11-132.

Ireland, R.R. \& Buck, W.R. 2009. Some Latin American genera of Hypnaceae (Musci). Smithsonian Contributions to Botany, 93 $1-97$.

Ireland, R.R., Bellolio, B., Bednarek-Ochyra, H. \& Ochyra, R. 2005 Fertile plants of Racomitrium patagonicum (Bryopsida, Grimmiaceae). Journal of the Hattori Botanical Laboratory, 98: 205-11.

Janovicová, K. \& Kubinská, A. 2002. Súčasný stav poznania bryoflóry Záhorskej nížiny (JZ Slovensko). Bulletin Slovenskej Botanickej Spoločnosti, 24: 55-9.

Jiménez, J.A. 2006. Taxonomic revision of the genus Didymodon Hedw. (Pottiaceae, Bryophyta) in Europe, North Africa, and southwest and central Asia. Journal of the Hattori Botanical Laboratory, 100: 211-92.

Köckinger, H., Schröck, C., Krisai, R. \& Zechmeister, H.G. 2016. Checklist of Austrian Bryophytes. [Accessed 10 March 2016] Available at: http://131.130.59.133/projekte/moose/

Kučera, J. 2000. Illustrierter Bestimmungsschlüssel zu den mitteleuropäischen Arten der Gattung Didymodon. Meylania, 19: 2-49.

Kučera, J. (ed.), 2005. Mechorosty České republiky—on-line klíče, popisy a ilustrace. http://botanika.bf.jcu.cz/bryoweb/klic/.

Kučera, J. \& Ignatov, M.S. 2015. Revision of phylogenetic relationships of Didymodon sect. Rufiduli (Pottiaceae, Musci). Arctoa, 24: 79-97.

Kürschner, H. \& Frey, W. 2011. Liverworts, mosses and hornworts of southwest Asia. (Marchantiophyta, Bryophyta, Anthocerotophyta). Nova Hedwigia, Beiheft 139: 1-240.

Kürschner, H., Batsatsashvili, K. \& Parolly, G. 2013. Noteworthy additions to the bryophyte flora of Georgia. Herzogia, 26 213-6.

Lara, F. \& Garilleti, R. 2014. Orthotrichum Hedw. In: J. Guerra, M.J. Cano \& M. Brugués, eds. Flora Briofitica Ibérica, Vol V. Murcia: Universidad de Murcia, Sociedad Española de Briología, pp. 50-135.

Lara, F., Mazimpaka, V., Medina, R., Caparrós, R. \& Gariletti, R. 2010. Northeastern Turkey, an unnoticed but very important area for the Orthotrichaceae (Bryophyta). Nova Hedwigia Beiheft, 138: 165-80

Lavocat Bernarda, E. \& Schäfer-Verwimp, A. 2011. Checklist of the bryophytes of the Guadeloupe Archipelago and Martinique (French West Indies). Cryptogamie, Bryologie, 32(3): 233-72.

Lewinsky, J. 1992. The genus Orthotrichum Hedw. (Orthotrichaceae, Musci) in southeast Asia. A taxonomic revision. Journal of the Hattori Botanical Laboratory, 72: 1-88.

Lewinsky, J. \& van Rooy, J. 1990. New species and a new record of Orthotrichum from southern Africa: $O$. incurvomarginatum sp. nov., $O$. armatum sp. nov., $O$. oreophilum sp. nov. and $O$. firmum Vent. Journal of Bryology, 16: 67-78.

Lindberg, S.O. 1867. Förteckning over mossor, insamlade under de svenska expeditionerna till Spitsbergen 1858 och 1861 Öfversigt af Förhandlingar: Kongl. Svenska VetenskapsAkademien, 9: 41-88.

Lockhart, N., Hodgetts, N. \& Holyoak, D. 2012. Rare and threatened bryophytes of Ireland. Holywood: National Museums Northern Ireland.

Lüth, M. 2007. Additions to the bryophyte flora of Bulgaria. Cryptogamie, Bryologie, 28(3): 237-41

Martinčič, A. 2009. Contributions to the bryophyte flora of Republic of Macedonia. Hacquetia, 8/2: 97-114

Matteri, C.M. 1986. Los Musci (Bryophyta) de las Islas Malvinas, su habitat y distribución. Nova Hedwigia, 43: 159-89.

Matteri, C.M. 2003. Los musgos (Bryophyta) de Argentina. Tropical Bryology, 24: 33-100.

Melosik, I. 1992. Distribution of Sphagnum molle Sull. in Poland Badania Fizjograficzne nad Polska Zachodnia, Seria B, Botanika, 41: 281-90.

Moen, T.L. 2013. Bryum gemmiferum. Norwegian Biodiversity Information Center [accessed 10 March 2016]. Available at: http://www2.artsdatabanken.no/artsnavn/Contentpages/Sok .aspx

Morales, T. \& Moreno, E. 2010. Contribución al conocimiento de los briofitos epifilos de Venezuela. Ernstia, 20(1): 47-79.

Müller, F. 2009. An updated checklist of the mosses of Chile. Archive for Bryology, 58: 1-124.
Murray, B.M. 2006. Andreaeaceae. In: P. M. McCarthy, ed. Flora of Australia. Vol. 51 Mosses 1. Melbourne: CSIRO Publishing, pp. $108-23$

Natcheva, R. ed. 2008. New bryophyte records in the Balkans: 4 . Phytologia Balcanica, 14(1): 125-30.

Nöske, N., Gradstein, S.R., Kürschner, H., Parolly, G. \& Torrachi, S. 2003. Cryptogams of the Reserva Biológica San Francisco (Provincia Zamora-Chinchipe, Southern Ecuador). I. Bryophytes. Cryptogamie, Bryologie, 24: 15-32.

Ochi, H. 1980. A revision of the Neotropical Bryoideae, Musci (first part). Journal of the Faculty of Education Tottori University, 29: 49-154

Ochyra, R. 1985a. Hypnobartlettia fontana gen. et sp. nov. (Musci: Hypnobartlettiaceae fam. nov.), a unique moss from New Zealand. Lindbergia, 11: 2-8.

Ochyra, R. 1985b. Koponenia, a new pleurocarpous moss genus from Bolivia. Journal of Bryology, 13(4): 479-86.

Ochyra, R. 1986a. Touwia laticostata, a remarkable new genus and species of moss from Queensland, Australia. Journal of Bryology, 14: 103-8.

Ochyra, R. 1986b. On the taxonomic position of Sciaromium lacustre Herz. \& Rich. in Rich. Journal of Bryology, 14: 109-15.

Ochyra, R. 1987a. On the taxonomy and family placement of the moss genus Limbella (C. Muell.) Broth. Journal of Bryology, 14: $465-85$

Ochyra, R. 1987b. A revision of the moss genus Sciaromium (Mitt.) Mitt. I. General remarks and the section Aloma Dusén. Journal of Bryology, 14: 453-64.

Ochyra, R. 1987c. A revision of the moss genus Sciaromium (Mitt.) Mitt. II. The section Limbidium Dusén, with a description of Vittia gen. nov. (Vittiaceae fam. nov.). Journal of the Hattori Botanical Laboratory, 62: 387-415.

Ochyra, R. 2010. Antipodal mosses: XVI. The first record of the genus Sematophyllum (Sematophyllaceae) in the Subantarctic, with a description of $S$. lebouvieri sp. nov. Cryptogamie Bryologie, 31(3): 223-32.

Ochyra, R. 2013. On the identity of Hygroamblystegium crassicostatum E.B.Bartram (Amblystegiaceae) from Chile. Journal of Bryology, 35(2): 147-9.

Ochyra, R. \& Bednarek-Ochyra, H. 2011. Schistidium deguchianum (Grimmiaceae), a new Andean species of from Peru. Journal of Bryology, 33(3): 189-94.

Ochyra, R. \& Bednarek-Ochyra, H. 2013. On the identity of Ditrichum validinervium (Bryophyta, Ditrichaceae). Cryptogamie, Bryologie, 34(3): 299-306.

Ochyra, R. \& Broughton, D.A. 2004. New moss records from the Falkland Islands. Journal of Bryology, 26(3): 226-30.

Ochyra, R. \& Enroth, J. 1989. Neckeropsis touwii (Musci, Neckeraceae), new species from Papua New Guinea, with an evaluation of sect. Pseudoparaphysanthus of Neckeropsis. Annales Botanici Fennici, 26: 127-32.

Ochyra, R. \& Ireland, R.R. 2016. Isopterygium tenerifolium (Hypnaceae, Bryophyta) - one more Afro-American disjunct. Herzogia, 29(1): 72-8.

Ochyra, R. \& Lewis Smith, R.I. 1998. Antarctic species in the genus Ditrichum (Ditrichaceae, Bryopsida), with a description of $D$. gemmiferum sp. nov. Annales Botanici Fennici, 35: 33-53.

Ochyra, R. \& Lightowlers, P.J. 1988. The South Georgian moss flora: Vittia. British Antarctic Survey Bulletin, 80: 121-7.

Ochyra, R. \& Shevock, J.R. 2012. A fruiting plant of Handeliobryum sikkimense (Bryopsida, Thamnobryaceae) from Yunnan, China. Nova Hedwigia, 94: 307-21.

Ochyra, R. \& Vanderpoorten, A. 1999. Platyhypnidium mutatum, a mysterious new moss from Germany. Journal of Bryology, 21 (3): 183-9.

Ochyra, R. \& van Rooy, J. 2013. Distribution of Bucklandiella lamprocarpa (Grimmiaceae, Musci) in South Africa. Cryptogamie, Bryologie, 34(3): 359-66.

Ochyra, R., Sergio, C. \& Schumacker, R. 1988. Racomitrium lamprocarpum (C. Muell.) Jaeg., an austral moss disjunct in Portugal, with taxonomic and phytogeographic notes. Bulletin du Jardin botanique national de Belgique / Bulletin van de National Plantentuin van België, 58: 225-58.

Ochyra, R., Bednarek-Ochyra, H., Pócs, T. \& Crosby, M.R. 1992. The moss Adelothecium bogotense in continental Africa, with a review of its world range. Bryologist, 95: 287-95.

Ochyra, R., Schmidt, C. \& Bültmann, H. 1998. Gradsteinia torrenticola, a new aquatic moss species from Tenerife. Journal of Bryology, 20(2): 403-9. 
Ochyra, R., Bednarek-Ochyra, H. \& Lewis Smith, R.I. 2002a. New and rare moss species from subantarctic South Georgia. Nova Hedwigia, 74: 121-47.

Ochyra, R., Wesche, K., Miehe, G. \& Miehe, S. 2002b. New records of pleurocarpous mosses for Africa and Uganda. Journal of Bryology, 24(3): 256-9.

Ochyra, R., Lewis Smith, R.I. \& Bednarek-Ochyra, H. 2008a. The illustrated moss flora of Antarctica. Cambridge: Cambridge University Press.

Ochyra, R., Bednarek-Ochyra, H. \& Lewis Smith, R.I. 2008b. New and rare moss species from the Antarctic. Nova Hedwigia, 87: 457-77.

Ochyra, R., Crabtree, D. \& Tangney, R. 2015a. Studies on mosses in the Falkland Islands: I. Bucklandiella and Codriophorus (Grimmiaceae). Cryptogamie, Bryologie, 36(3): 289-310.

Ochyra, R., Sollman, P. \& Lebouvier, M. 2015b. Hymenostylium recurvirostrum (Pottiaceae), a moss genus and species newly discovered in the southern polar regions. Herzogia, 28: 599-606.

Osyczka, P., Flakus, A., Wegrzyn, M. \& Cykowska, B. 2007. Cladonia crispata var. cetrariiformis (Cladoniaceae, lichenized Ascomycota) in the Tatra Mts. Biologia, 62(2): 144-7.

Papp, B., Erzberger, P., Odor, P., Hock, Zs., Szövényi, P., Szurdoki, E. \& Tóth, Z. 2010. Updated checklist and red list of Hungarian bryophytes. Studia Botanica Hungarica, 41: 31-59.

Partyka, L.Ya. 2005. Brioflora Kryma [The bryoflora of the Crimea]. Kiev: Fitosociocentr.

Peralta, D.F. 2016. Hypnaceae. In: Lista de espécies da flora do Brasil. Jardim Botânico do Rio de Janeiro. [Accessed 24 April 2016]. Available at < http://floradobrasil.jbrj.gov.br/ jabot/floradobrasil/FB96447>

Pilous, Z. 1991. Poznámky k článku A. Kubinské “Chránené druhy machorastov". Bryonora, 7: 5.

Plášek, V., Sawicki, J., Trávníčková, V. \& Pasečná, M. 2009. Orthotrichum moravicum (Orthotrichaceae), a new moss species from the Czech Republic. Bryologist, 112: 329-36.

Plášek, V., Sawicki, J. \& Č́hal, L. 2014. Orthotrichum pamiricum (Bryophyta), a new epiphytic moss species from Pamir Mountains in Central Asia. Turkish Journal of Botany, 38: 754-62.

Potemkin, A.D. \& Sofronova, E.V. 2009. Liverworts and hornworts of Russia. Boston: V. I. S. Petersburg-Yakutsk.

Potier de la Varde, R. 1936. Mousses du Gabon. Mémoires de la Societe des Sciences Naturelles et Mathématiques de Cherbourg, 42, ser. 5, 2: 1-270.

Potier de la Varde, R. 1955. Mousses récoltées par M. le Dr. Olov Hedberg, en Afrique orientale, au cours de la mission suédoise de 1948. Arkiv för Botanik, 3: 125-204.

Preston, C.D. \& Blockeel, T.L. 2006. Field meeting, FebruraryMarch 2006, Salerno-Italy. Bulletin of the British Bryological Society, 90: 38-45.

Printarakul, N., Tan, B.C., Santanachote, K. \& Akiyama, H. 2013. New and noteworthy records of mosses from Doi (Mt.) Inthanon, Chiang Mai, Chom Tong District, northern Thailand. Polish Botanical Journal, 58(1): 245-57.

Privitera, M. \& Cenci, R.M. 2007. Limiti e progressi della bioindicazione briofitica nell'area Mediterranea. $102^{\circ}$ Congresso della Società Botanica Italiana, 26-29 Settembre 2007: 199. Palermo.

Privitera, M. \& Puglisi, M. 1999a. Bryophyte vegetation of the badlands from the Aspromonte Massif (S Italy). Nova Hedwigia, 69 (1-2): 195-210

Privitera, M. \& Puglisi, M. 1999b. Indicizzazione della qualità ambientale attraverso l'uso della flora briofitica. Un esempio di studio su Vulcano (Isole Eolie). Archivio Geobotanico, 5(12): $77-83$

Puglisi, M., Privitera, M. \& Ferro, G. 2006. Outlines of the bryophyte vegetation of Vulcano (Aeoliana Islands, Sicily). Fitosociologia, 43: 85-95

Rensing, S.A., Lang, D., Zimmer, A.D., Terry, A., Salamov, A Shapiro, H., Nishiyama, T., Perroud, P.F., Lindquist, E.A., Kamisugi, Y., Tanahashi, T., Sakakibara, K., Fujita, T., Oishi, K., Shin-I, T., Kuroki, Y., Toyoda, A., Suzuki, Y., Hashimoto, S., Yamaguchi, K., Sugano, S., Kohara, Y., Fujiyama, A. Anterola, A., Aoki, S., Ashton, N., Barbazuk, W.B., Barker, E., Bennetzen, J.L., Blankenship, R., Cho, S.H., Dutcher, S.K., Estelle, M., Fawcett, J.A., Gundlach, H., Hanada, K. Heyl, A., Hicks, K.A., Hughes, J., Lohr, M., Mayer, K. Melkozernov, A., Murata, T., Nelson, D.R., Pils, B., Prigge, M., Reiss, B., Renner, T., Rombauts, S., Rushton, P.J., Sanderfoot, A., Schween, G., Shiu, S.H., Stueber, K.
Theodoulou, F.L., Tu, H., Van de Peer, Y., Verrier, P.J., Waters, E., Wood, A., Yang, L., Cove, D., Cuming, A.C., Hasebe, M., Lucas, S., Mishler, B.D., Reski, R., Grigoriev, I.V., Quatrano, R.S. \& Boore, J.L. 2008. The Physcomitrella genome reveals evolutionary insights into the conquest of land by plants. Science, 319(5859): 64-9.

Ros, R.M., Mazimpaka, V., Aleffi, M., Blockeel, T.L., Cano, M.J., Cros, R.M., Dia, M.G., Dirkse, G.M., Saadawi, W.El., Ganeva, A., González-Mancebo, J.M., Herrnstadt, I., Khalil, K., Kürschner, H., Lanfranco, E., Losada-Lima, A., Refai, M.S., Rodríguez-Nuñez, S., Sabovljević, M., Sérgio, C., Shabbara, H., Sim-Sim, M. \& Söderström, L. 2007. Hepatics and Anthocerotes of the Mediterranean, an annotated checklist. Cryptogamie, Bryologie, 28(4): 351-437.

Ros, R.M., Mazimpaka, V., Abou-Salama, U., Aleffi, M., Blockeel, T.L., Brugués, M., Cros, R.M., Dia, M.G., Dirkse, G.M., Draper, I., El-Saadawi, W., Erdă̌ , A., Ganeva, A., Gabriel, R., González-Mancebo, J.M., Granger, C., Herrnstadt, I., Hugonnot, V., Khalil, K., Kürschner, H., Losada-Lima, A., Luís, L., Mifsud, S., Privitera, M., Puglisi, M., Sabovljević, M., Sérgio, C., Shabbara, H.M., Sim-Sim, M., Sotiaux, A., Tacchi, R., Vanderpoorten, A. \& Werner, O. 2013. Mosses of the Mediterranean, an annotated checklist. Cryptogamie, Bryologie, 34(2): 99-283.

Schäfer-Verwimp, A. \& Gruber, J.P. 2002. Orthotrichum (Orthotrichaceae, Bryopsida) in Pakistan. Tropical Bryology, 21: 1-9.

Schäfer-Verwimp, A., Lehnert, M. \& Nebel, M. 2013. Contribution to the knowledge of the bryophyte flora of Ecuador. Phytotaxa, 128: 1-63.

Schiffner, V. 1913. Bryophyta aus Mesopotamien und Kurdistan, Syrien, Rhodos, Mytilini und Prinkipo. Annalen des Naturhistorischen Museums Wien, 27: 472-504.

Schuster, R.M. 1969. The Hepaticae and Anthocerotae of North America, east of the hundredth meridian, Vol. 2. New York and London: Columbia University Press, pp. 300-5.

Sérgio, C. \& Sim-Sim, C. 2012. Andreaea flexuosa R. Brown Bis subsp. luisieri Sérgio et Sim-Sim (Andreaeaceae), a new taxon from Madeira Island. Cryptogamie, Bryologie, 33(3): 271-7.

Shevock, J.R., Ochyra, R., He, S. \& Long, D.G. 2011. Yunnanobryon, a new rheophytic moss genus from southwest China. Bryologist, 114: 194-203.

Skrzypczak, R. \& Skrzypczak, J.F. 2000. Contribution à la bryoflore des Hautes-Alpes (suite). Bulletin de la Société Botanique du Centre-Ouest, n.s., 31: 479-84

Smith, A.J.E. 1978. The moss flora of Britain and Ireland. Cambridge: Cambridge University Press.

Smith, A.J.E. 2004. The moss flora of Britain and Ireland. 2nd edn. Cambridge: Cambridge University Press.

Söderström, L., Hagborg, A., von Konrat, M., Bartholomew-Began, S., Bell, D., Briscoe, L., Brown, E., Cargill, D.C., Costa, D.P., Crandall-Stotler, B.J., Cooper, E.D., Dauphin, G., Engel, J.J., Feldberg, K., Glenny, D., Gradstein, S.R., He, X., Heinrichs, J., Hentschel, J., Ilkiu-Borges, A.L., Katagiri, T., Konstantinova, N.A., Larraín, J., Long, D.G., Nebel, M., Pócs, T., Puche, F., Reiner-Drehwald, E., Renner, M.A.M., Sass-Gyarmati, A., Schäfer-Verwimp, A., Segarra-Moragues, J.G., Stotler, R.E., Sukkharak, P., Thiers, B.M., Uribe, J., Váňa, J., Villarreal, J.C., Wigginton, M., Zhang, L. \& Zhu, R.-L. 2016. World checklist of hornworts and liverworts. PhytoKeys, 59: 1-828

Soldán, Z. \& Kučera, J. 2004. Bryum gemmiferum, nový druh bryóflory České Republiky [Bryum gemmiferum, new species in the bryoflora of the Czech Republic]. Bryonora, 33: $1-5$.

Ştefănut, S. \& Goia, I. 2012. Checklist and red list of bryophytes of Romania. Nova Hedwigia, 95(1-2): 59-104.

Tan, B.C. \& Jia, Y. 1999. A preliminary revision of Chinese Sematophyllaceae. Journal of the Hattori Botanical Laboratory, 86: 1-70.

Tavares-Martins, A.C.C., Lisboa, R.C.L. \& Costa, D.P. 2014 Bryophyte flora in upland forests at different successional stages and in the various strata of host trees in northeastern Pará, Brazil. Acta Botanica Brasilica, 28(1): 46-58.

Toren, D. \& Heise, K. 2009. Bryum chryseum Mitt. (Musci: Bryaceae) new to North America north of Mexico. Evansia, 26: $98-101$

Touw, A. \& Ochyra, R. 1987. Additional notes on Neckeropsis 2. Lindbergia, 13: 97-104. 
Universidade Federal de Minas Gerais 2015. Estação Ecológica da UFMG. [Accessed 1 May 2014]. Available at: <http://www ufmg.br/estacaoecologica>

Uribe, M.J. \& Gradstein, S.R. 1998. Catalogue of the Hepaticae and Anthocerotae of Colombia. Bryophytorum Bibliotheca, 53 $1-99$.

Valente, E.B. \& Pôrto, K.C. 2006. Hepáticas (Marchantiophyta) de um fragmento de Mata Atlântica na Serra da Jibóia, Município de Santa Teresinha, BA, Brasil. Acta Botanica Brasilica, 20(2): 433-41.

Váňa, J., Söderström, L., Hagborg, A. \& von Konrat, M. 2014. Notes on early land plants today. 52. Validation of Tritomaria camerunensis (Lophoziaceae, Marchantiophyta). Phytotaxa, 167(2): 215-6.

Vanderpoorten, A. \& Zartman, C.E. 2002. The Bryum bicolor complex in North America. Bryologist, 105(1): 128-39.

Van der Putten, N., Stieperaere, H., Verbruggen, C. \& Ochyra, R. 2004. Holocene palaeoecology and climate history of South Georgia (sub-Antarctica) based on a macrofossil record of bryophytes and seeds. The Holocene, 14: 382-92.

Van der Putten, N., Verbruggen, C., Ochyra, R., Spassov, S., de Beaulieu, J.-L., De Dapper, M., Hus, J. \& Thouveny, N. 2009. Peat bank growth, Holocene palaeoecology and climate history of South Georgia (sub-Antarctica), based on a botanical macrofossil record. Quaternary Science Reviews, 28: 65-79.

Van der Putten, N., Verbruggen, C., Ochyra, R., Verleyen, E. \& Frenot, Y. 2010. Subantarctic flowering plants: pre-glacial survivors or post-glacial immigrants? Journal of Biogeography, 37: 582-92.

von Schwartzenberg, K. 2009. Hormonal regulation of development by auxin and cytokinin in moss. Annual Plant Reviews, 36: 246-81.

Wang, Q. \& Jia, Y. 2014. Taxonomic status of Ulota tanganyikae P.de la Varde (Orthotrichaceae, Bryopsida) from Africa. Journal of Bryology, 36: 78-81.

Wegener, C., Hansen, M. \& Jacobsen, L.B. 1992 Vegetasjonsovervåking på Svalbard 1991. Effekter av reinbeite ved Kongsfjorden, Svalbard. Norsk Polarinstitutt Medd., 121: $1-53$.
Węgrzyn, M. \& Wietrzyk, P. 2015. Phytosociology of snowbed and exposed ridge vegetation of Svalbard. Polar Biology, 38(11): 1905-17.

Wegrzyn, M., Lisowska, M. \& Nicia, P. 2013. The value of the terricolous lichen Cetrariella delisei in the biomonitoring of heavymetal levels in Svalbard. Polish Polar Research, 34(4): 375-82.

Werner, J. 1994. Observations bryologiques au Grand-Duché de Luxembourg. $10^{\mathrm{e}}$ série: 1993. Bulletin de la Société des Naturalistes, Luxembourg, 95: 135-42.

Werner, O., Jiménez, J.A., Ros, R.M., Cano, M.J. \& Guerra, J. 2005. Preliminary investigation of the systematics of Didymodon (Pottiaceae, Musci) based on nrITS sequence data. Systematic Botany, 30: 461-70.

Wilbraham, J. \& Matcham, H.W. 2010. Zygodon oeneus Herzog (Bryophyta: Orthotrichaceae) new to Uganda and Africa. Journal of Bryology, 32(3): 237-9.

Wilczek, R. \& Demaret, F. 1976. Les espèces belges du 'complexe Bryum bicolor' (Musci). Bulletin du Jardin botanique national de Belgique / Bulletin van de National Plantentuin van België, 46: $511-41$

Yamada, K. 1986. An alphabetical list of the species and infraspecific taxa of the genus Radula (Radulaceae). Journal of the Hattori Botanical Laboratory, 60: 175-86.

Yamada, K. 1993. Notes on the type specimens of Radula taxa from Latin America 6. Journal of the Hattori Botanical Laboratory, 73: $125-37$

Yamada, K. 2003. Radulaceae. In: S. R. Gradstein \& D. P. Costa, eds The Hepaticae and Anthocerotae of Brazil. Memoirs of the New York Botanical Garden, 87: 228-35.

Zander, R.H. 2007. Didymodon. In: Flora of North America Editorial Committee, ed., Flora of North America north of Mexico, Vol. 27. New York: Oxford University Press, pp. 539-61.

Zarnowiec, J., Stebel, A. \& Ochyra, R. 2004. Threatened moss species in the Polish Carpathians in the light of a new Red-list of mosses in Poland. In: A. Stebel \& R. Ochyra, eds. Bryological studies in the Western Carpathians. Poznań: Sorus, pp. 9-28.

Zerov, D.K. \& Partyka, L.Ya. 1975. Mokhopodibni Ukrains'kykh Karpat [Bryophytes of the Ukrainian Carpathians]. Kiev: Naukova Dumka [In Ukrainian]. 